\title{
Article \\ Direct-Contact Air, Gravel, Ground Heat Exchanger in Air Treatment Systems for Cowshed Air Conditioning
}

\author{
Maciej Besler*(D), Wojciech Cepiński (D) and Piotr Kęskiewicz *(D) \\ Department of Air Conditioning, Heating, Gas Engineering, and Air Protection, \\ Faculty of Environmental Engineering, Wroclaw University of Science and Technology, 50-370 Wroclaw, Poland; \\ wojciech.cepinski@pwr.edu.pl \\ * Correspondence: maciej.besler@pwr.edu.pl (M.B.); piotr.keskiewicz@pwr.edu.pl (P.K.)
}

Citation: Besler, M.; Cepiński, W.; Kęskiewicz, P. Direct-Contact Air, Gravel, Ground Heat Exchanger in Air Treatment Systems for Cowshed Air Conditioning. Energies 2022, 15, 234. https://doi.org/10.3390/ en15010234

Academic Editor: Jose

A. Almendros-Ibanez

Received: 24 November 2021

Accepted: 25 December 2021

Published: 30 December 2021

Publisher's Note: MDPI stays neutral with regard to jurisdictional claims in published maps and institutional affiliations.

Copyright: (C) 2021 by the authors. Licensee MDPI, Basel, Switzerland. This article is an open access article distributed under the terms and conditions of the Creative Commons Attribution (CC BY) license (https:// creativecommons.org/licenses/by/ $4.0 /)$.

\begin{abstract}
This paper describes the analysis of the possibility of use of the direct-contact air, gravel, ground heat exchanger (acronym GAHE), patented at the Wroclaw University of Science and Technology, as a means of improving microclimate parameters in dairy cows' barns. Different possibilities of introducing GAHE to the standard mechanical ventilation system of cowsheds have been proposed and investigated. Based on literature data, the required air parameters in the barns of dairy cows were determined and discussed. Computer simulations were carried out and the results obtained were compared to the baseline model. Year-round changes in microclimate parameters, especially air temperature, relative humidity, and THI index were investigated. The benefits of GAHE use were indicated. The possible increase in the minimum air volume of ventilation during the winter season and the decrease in the maximum values of this parameter in the summer were presented. Indications were made of the systems where the application of GAHE could be the most beneficial. A further research path has been proposed.
\end{abstract}

Keywords: natural energy; ground energy; soil—air exchanger; efficiency; dairy farming

\section{Introduction}

\subsection{Reasons for Raising the Issue}

Agriculture is one of the three main sectors of the national economy (outside industry and services), for which the overriding goal is the production of food. Agricultural production is divided into the cultivation of plants and animals. Plant cultivation provides, among others, cereal, vegetable, and fruit grains. Due to animal husbandry, we have mainly meat, in addition dairy products, fats, milk, skins, and others.

There is a need to look for solutions that can significantly improve production without a negative impact on the environment.

In a world where there is a lack of sources of energy, along with the major usage of traditional fossil fuels, there is a high demand to find better solutions to use more environmentally friendly energy, which exists in nature and is easily accessible.

When planning, designing, and improving projects, it is important to focus on the following: legal requirements, investment costs, production efficiency, and the growing knowledge and trend of saving and renewing energy, along with the positive or negative impact it will cause.

\subsection{The Air Direct-Contact, Gravel, Ground Heat Exchanger (GAHE)}

At the Institute of Air Conditioning and District Heating of the Wroclaw University of Science and Technology, for more than 30 years in-depth research has been carried out on the efficient extraction of natural thermal energy (including cold), from a shallow depth of the ground, in the air direct-contact, gravel, ground heat exchanger for ventilation and air-conditioning purposes [1]. 
The ground at a depth of $4-5 \mathrm{~m}$ in a Central European climate has a relatively constant temperature all year round similar to the average outdoor temperature $\left(8-12^{\circ} \mathrm{C}\right)$. A device to heat up air during winter and cool it down during summer can be constructed by placing the heat-exchanging gravel bed of appropriate volume at a smaller depth or even at a ground surface level. This is how GAHE works. The construction of GAHE is very simple and relatively inexpensive to build. The exchanger can be installed almost anywhere on the grounds of the property. The air-after passing through the heat exchanger-also contains much fewer cells of microorganisms than that contained at the inlet. Both the number of bacteria and fungi decrease significantly. Thus, the exchanger acts as a kind of effective air filter. This type of ground heat exchanger construction is not recommended to be used in soils or with fills containing radon particles.

\subsection{Required Air Parameters for Cowshed}

Livestock buildings are places where animals spend most of their lives. They provide protection against the adverse impact of external conditions while ensuring appropriate internal conditions, consistent with animal welfare requirements. The proper microclimate is affected by the temperature and humidity of the air, proper ventilation of the rooms, concentration of harmful gases, acoustics, and the type of lighting. The microclimate conditions in cowsheds significantly affect the productivity and welfare of animals, their health, comfort, development, and longevity. The microclimate in the cowshed is especially important. It should be understood that, above all, proper air parameters in the animal residence zone have to be ensured and its impact on the condition of the building and its external walls should be considered.

As shown in Table 1, below, optimal temperature for cow breeding is in the range between 8 and $16^{\circ} \mathrm{C}$, and then the production is the most efficient. It is not recommended that the air temperature in the animal residence zone drops below $0{ }^{\circ} \mathrm{C}$. The optimal humidity for cows is in the range of $50-80 \%$. It is also important to properly ventilate this zone to eliminate drafts.

On the other hand, the German standard presented in [2] recommends that the air temperatures in the animal residence zone be maintained in the range of $0-20^{\circ} \mathrm{C}\left(7-17^{\circ} \mathrm{C}\right.$ for milk production) in mechanically ventilated barns.

Table 1. Recommended ranges of temperature and humidity for cowsheds [3].

\begin{tabular}{|c|c|c|c|c|c|c|c|c|c|}
\hline \multirow{2}{*}{$\begin{array}{c}\text { Animals } \\
-\end{array}$} & \multicolumn{3}{|c|}{ Temperature, ${ }^{\circ} \mathrm{C}$} & \multicolumn{2}{|c|}{$\begin{array}{c}\text { Relative } \\
\text { Humidity, \% }\end{array}$} & \multicolumn{2}{|c|}{ Airflow Rate, m/s } & \multicolumn{2}{|c|}{$\begin{array}{l}\text { Air Exchange, } \\
\mathrm{m}^{3} / \mathrm{h}\end{array}$} \\
\hline & Min. & Opt. & Max & Opt. & Max & Winter & Summer & Winter & Summer \\
\hline Dairy cows & 6 & $8-16$ & 25 & $60-80$ & 85 & $0.1-0.3$ & 0.5 & 90 & $350-400$ \\
\hline Cows in the delivery room & 16 & $16-20$ & 25 & $60-80$ & 85 & $0.1-0.2$ & 0.4 & 90 & $350-400$ \\
\hline Calves in a preventive treatment & 12 & $16-20$ & 30 & $60-80$ & 85 & $0.1-0.2$ & 0.3 & 20 & 80 \\
\hline $\begin{array}{l}\text { Calves up to } 6 \text { months old } \\
\text { maintained in the system: }\end{array}$ & & & & & & & & 30 & $90-120$ \\
\hline - bedding & 8 & $12-16$ & 25 & $60-80$ & 85 & $0.1-0.3$ & 0.3 & 30 & $90-120$ \\
\hline - bedding free & 12 & $12-20$ & 25 & $60-80$ & 85 & $0.1-0.3$ & 0.3 & 30 & $90-120$ \\
\hline $\begin{array}{l}\text { Heifers under } 6 \text { months in the room } \\
\text { for the period of treatment }\end{array}$ & 16 & $17-20$ & 25 & $60-80$ & 85 & $0.1-0.3$ & 0.5 & 60 & 250 \\
\hline Cattle over 6 months & 6 & $10-18$ & 25 & $60-80$ & 85 & $0.1-0.3$ & 0.5 & 70 & 280-300 \\
\hline \multicolumn{10}{|c|}{ Permissible concentration of admixtures in the air: } \\
\hline Carbon dioxide $\left(\mathrm{CO}_{2}\right)$ & & $0.25000 \%$ & & & & & & & \\
\hline Ammonia $\left(\mathrm{NH}_{3}\right)$ & & $0.00260 \%$ & & & & & & & \\
\hline Hydrogen sulfide $\left(\mathrm{H}_{2} \mathrm{~S}\right)$ & & $0.00100 \%$ & & & & & & & \\
\hline
\end{tabular}

In Figure 1, areas are presented that show the nature of the variability of the outdoor air and the air after GAHE, recorded in the second climatic zone of Poland. Moreover, in this graphic the so-called climatic curve is indicated, showing the average outdoor air parameters of the geographical area of Poland and the typical thermal comfort parameters 
of the cowsheds. Curves of selected temperature-humidity index (THI, described further in Section 1.4 of this paper) values are also shown.

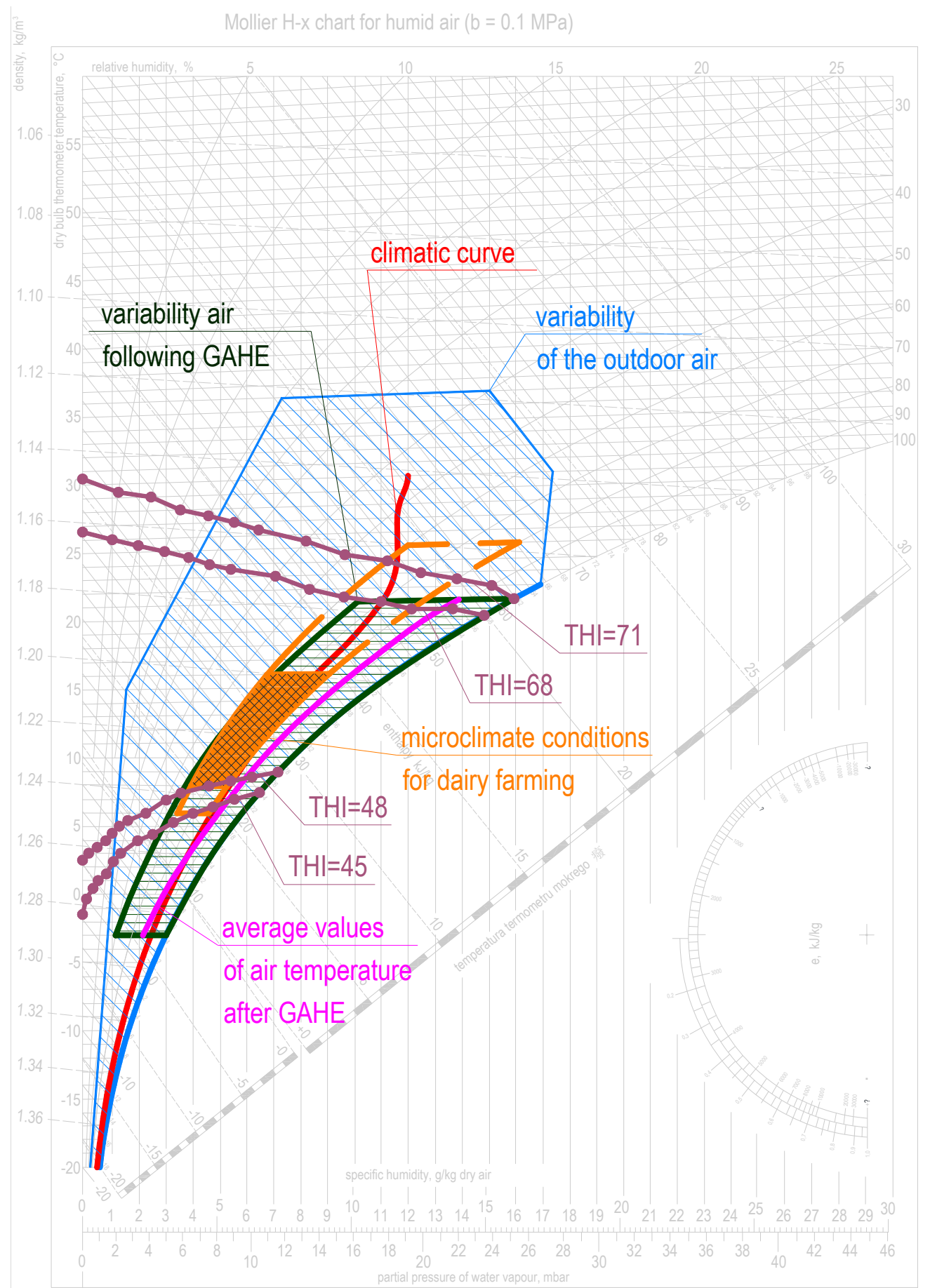

Figure 1. Ranges of changes in air parameters in the Mollier diagram.

It can be seen that the recommended air parameters in dairy-cow barns are more restrictive than the recommended THI range. The maximum allowable air parameters exceed this range, which means that these parameters should be analyzed together.

Studies [4] show that keeping animals in cool, damp, insufficiently ventilated rooms with drafts reduces their productivity by up to $15 \%$, increases food consumption by $12-35 \%$, and coat density, resulting in morbidity greater by $2-3$ times. An inappropriate microclimate also affects the overall condition of the livestock building, its durability, and the indoor 
thermal conditions. When the air temperature is above $25^{\circ} \mathrm{C}$, cows eat less, and their milk yield and weight gains decrease. The most unfavorable combination of parameters is set of high temperature with high humidity (over $80 \%$ ) and a small exchange of air. In this case, so-called heat stress may occur among cattle. Relatively high humidity prevents animals from releasing heat into the environment by evaporating from the body surface. If indoor air is highly polluted, due to low air exchange, also known as poor ventilation, the humidity will usually be high. Such conditions result in the increased development and spread of bacteria and viruses. Relatively high humidity also requires more litter, because it is difficult to keep the area dry. Moistened surfaces in the room also shorten the life of the building and in the winter increase the cost of its maintenance.

Therefore, it is important to ensure proper ventilation. If maintenance of the proper microclimate in the entire cubature of the room is not possible, better parameters should be applied at least in the animal residence zone. Particularly beneficial microclimate parameters should be provided in the waiting room and feed-table area, which can be achieved by more intensive venting of these zones or adding cooling or spraying of animals.

Ventilation can be gravitational or mechanical. It is important to emphasize that mechanical ventilation requires the installation of an alarm system, as well as emergency ventilating.

In addition, in cowsheds there are emissions of various types of organic and inorganic dust, odors, and harmful gases that affect not only the animals, but also the people working in the barn. As an example, one can distinguish, as an example: ammonia, methane, nitrous oxide, hydrogen sulfide, carbon monoxide, and carbon dioxide, the emission sources of which are animal feces, in the form of both slurry and manure, litter, and feed. However, a major source of methane is intestinal fermentation and the emission of metabolic products. Table 1 shows the permissible concentrations of selected pollutants. The variability of ammonia concentration in cowsheds and the factors influencing it in different periods of the year are described in [5]. The method of reducing odors with the use of wood filters is described in [6]. Overall, barn ventilation should ensure proper dilution and effective pollutants' removal to the outside.

Practice shows that for the warm period, a larger ventilation air volume should be assumed in cowsheds, while in the cold period, ventilation air volume should be limited to the minimum. The increased air volume during the warm period should prevent the barn from overheating during high outside air temperatures and high insolation. The air volume of the cold period should be reduced to prevent excessive cooling of the animal residence zone, while ensuring the possibility of assimilation and removal of harmful substances outside the cowshed.

Indirect and direct control strategies for the parameters presented above are described in [7].

\subsection{Temperature Stress on Dairy Cows}

It is very important to maintain optimal conditions of thermal comfort in the dairy (see Table 1).

When environmental temperatures fall out of the thermoneutral zone, dairy cattle begin to experience heat or cold stress. In those cases, conditions force cows to spend more energy to keep the temperature of the body in the proper range, and thus there is less energy available to produce milk [8]. The thermoneutral zone means the temperature range in which cows may use minimal amounts of energy to maintain body temperature at the correct level. The temperature range of the thermoneutral zone depends on age, breed, diet composition, housing and stall conditions, behavior of the animal, and others. The upper temperature limit is considered to be $25-26^{\circ} \mathrm{C}$. The lower temperature is given as a range from $-7.2^{\circ} \mathrm{C}$. [9].

Actual thermal conditions in the dairy may be above (heat stress) or below (cool stress) the thermoneutral zone; both are unfavorable. In warm-to-moderate climates, heat stress is a major problem for the welfare of dairy cattle welfare. 
European cattle tend to be tolerant to lower temperatures and are usually housed in cowsheds that further minimize the impact of outside air temperature fluctuations on the animals. It is the reason why the impact of cold stress on animal performance in cattle has received less research attention [8]. Relative air humidity is also important for the thermal comfort conditions in the dairy stall. The recommended range is shown in Table 1 [4].

The temperature-humidity index (THI) [9] is the most widely used environmental indicator. It can be used to determine the comfort climatic conditions in the dairy. The THI could be calculated according to the equation proposed by the National Research Council of the United States [10], from relative humidity and air temperature, and is calculated for a particular day according to the following formula: [11,12].

$$
T H I=(1.84 \cdot t+32)-(0.55-0.555 \cdot \varphi) \cdot(1.8 \cdot t-26),
$$

where $t$ is the dry bulb temperature $\left({ }^{\circ} \mathrm{C}\right)$ and $\varphi$ the relative humidity of the air $(\%)$.

Regardless of inside air temperature, as the relative humidity increases, it becomes more and more difficult for the animals to cool themselves. The thermal humidity conditions for which the THI values are 68 or less are considered comfortable. The values of 68-72 are considered mild discomfort, THI 72-75 as discomfort, THI 75-79 alert, THI 79-84 danger, and emergency for THI more than 84 [13].

As a result of being under thermal stress conditions, dairy cows show a number of signs, such as, among others [8,14]:

- panting with an increased respiration score (open-mouthed breathing),

- reduced feed intake,

- lethargy,

- increased sweating,

- rise in rectal temperature,

- reduced heart rate,

- decreased feed intake,

- increase water intake,

- drop in daily milk production,

- restlessness.

Figure 1 shows that, in the most unfavorable climatic conditions, the parameters of the air leaving GAHE do not exceed the value of the THI index equal to 70.

Other parameters can also affect milk production. In the article [15,16], it was indicated that milk production decreased with increasing THI. Decreased milk production was also observed with greater daily temperature fluctuations.

Thermal humidity stress, at THI more than 72 , has especially a negative impact on milk production and general health of cows $[13,17,18]$. Negative thermal climatic conditions can cause a decrease in milk production of between 3\% and 10\% [19].

Even occurrence of periodic evaporative cooling could have a negative effect on the respiratory rate of cows as presented in [20].

\subsection{Solution Idea}

The literature describes various solutions aimed at improving the microclimate conditions in cowsheds. The works [21,22] assessed the effectiveness of roof-mounted misting fans in improving the air temperature and humidity, which reduces the heat stress of animals. As another example, the effects of a tunnel ventilation systems are shown in [23].

The methods of modeling barns zones are described, as an example, in [24,25], where the coefficients of general and local air exchange were determined based on selected parameters.

The research and comparison of various variants of ventilation using CFD simulations are presented in [26,27]. In [28], the purposefulness of searching for algorithms and the use of automatic control systems for the operation of ventilation systems in cowsheds was confirmed. 
Typical solutions for the cowshed ventilation are shown in Figure 2a. External air through openings in external walls is supplied to the animal residence zone. The exhausted air is removed by ventilation ducts located in the upper part of the room.

a)
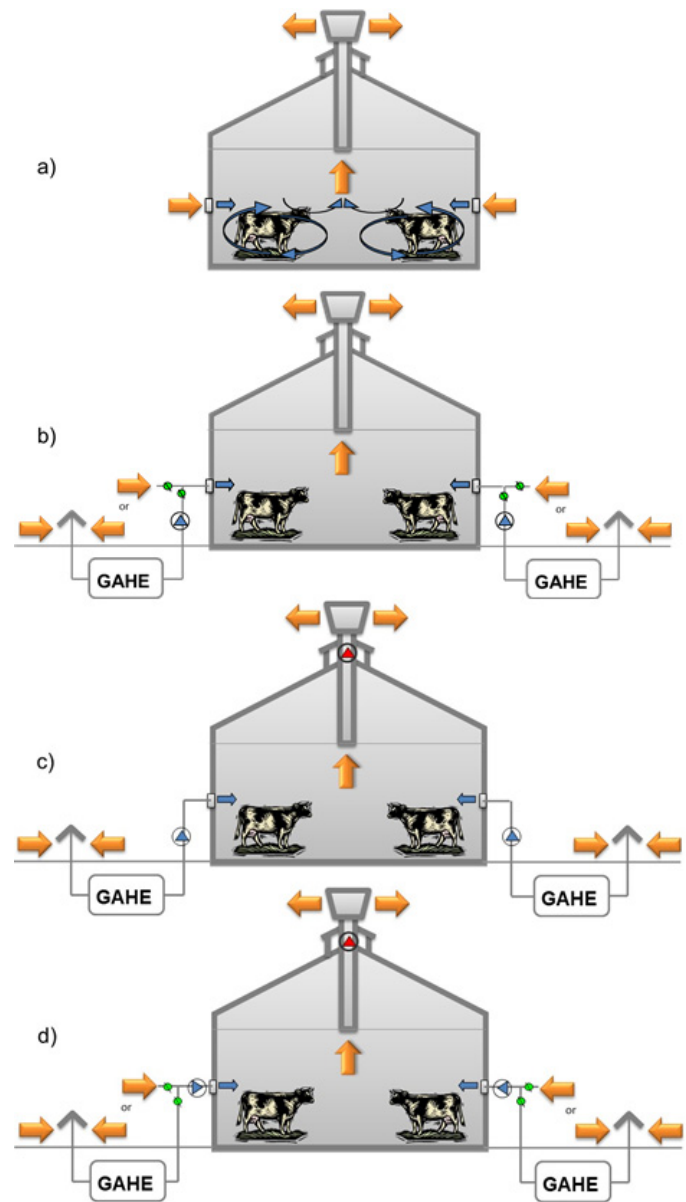

Figure 2. Schematic diagram of the ventilation system: (a) typical-natural ventilation, (b) proposed-natural or mechanical supply ventilation, (c) proposed-mechanical supply with GAHE and exhaust ventilation, (d) proposed-mechanical supply with or without GAHE and exhaust ventilation.

The original, innovative idea is to join the typical system with the air direct-contact, gravel, and ground heat exchanger (GAHE). This idea is presented in diagrams Figure $2 b-\mathrm{d}$. In Variant $4 b$, GAHE supports natural ventilation and can be used periodically as needed. In Variant 2c, the mechanical ventilation of the barn is provided through GAHE, and the air exhaust is supported (or not) by the exhaust fan. In Variant $2 \mathrm{~d}$, mechanical ventilation could use outside air or direct it through GAHE, the air exhaust is also supported (or not) by the exhaust fan. The use of both supply and exhaust mechanical ventilation allows better organization of air flow throughout the entire cowshed.

Depending on the time of year, heated or cooled air is supplied into the room, providing a more favorable microclimate. As a result of this, temperature fluctuations of air entering a building, as well as air already inside it, both in daily and seasonal cycle are considerably lower. This noticeably increases animal comfort and efficiency of production and provides beneficial effects of the use of GAHE.

\subsection{Research Gap and the Aims of the Paper}

On the basis of the literature review, it has been stated, that the subjects of heat gains, heat balance, and cowshed ventilation are widely discussed. However, the possible usage of a ground heat exchanger to improve the microclimate of the cowshed is not described in 
this context. In Poland, as well as the rest of the world, many modern cowsheds are being built where the application of such a solution would bring significant benefits, both in terms of microclimate parameters and overall cow comfort improvement and the resulting possibility of obtaining larger amounts of milk.

The research aims of the study were:

- determining the possibility of using a ground heat exchanger to provide microclimate parameters in a cowshed;

- determination of the influence of the type of ventilation and assumed air flows on microclimate;

- determining the areas of reasonable application of the analyzed solution.

\subsection{Novelty of the Work}

This paper presents an analysis of the GAHE:

- application in a barn of modern design,

- application for shaping the microclimate of a cowshed,

- $\quad$ supported ventilation performance compared to an installation without GAHE,

- supported ventilation-control-regiments proposal for the cowsheds.

\section{Materials and Methods}

\subsection{Analysis}

All analyses were performed in a simulation program EDSL TAS version 9.5.1, created by Environmental Design Solutions Limited. EDSL TAS is a graphical user interface program (GUI) based on EnergyPlus Engine. It is in use in many countries, both in design offices and in scientific institutions. First, a basic 3D cowshed model was created. Required constructions, weather data, internal conditions, and schedules were created and assigned. Then, on that basis, two final versions of the model were created: one equipped with a proper GAHE and the second without it. Simulations were performed, and results were obtained. The two-phase heat and mass transfer model in a ground exchanger, formulated by Kowalczyk [29], was used to simulate the operation of the ground exchanger.

Main analyses were conducted for Variant 2c.

The parameters of the created models and the obtained results are presented accordingly in Sections 3.1 and 3.2 of this article.

\subsection{Assumptions}

Cowshed is located within the second Polish climate zone, in Wrocław, with the external design temperature of $-18.0^{\circ} \mathrm{C}$. Two energy-simulation models were created on the basis of Wrocław's meteorological data (typical statistical weather data for building energy calculation published in ".epw" format by EnergyPlus [30], data translation was based on the information provided by Polish IMGW [4]). The basic model data used in all simulations and the cowshed geometry are presented in Table 2, Table 3, Table 4, Table 5, Figures 3 and 4 . Information on the building comprising construction parameters (external walls, ground floor, gable roof, glazing), type of use and schedules, localization, etc., were adopted on the basis of the design documentation and literature. The role of the shape of the outer structure of barns and the materials used for their construction are described, for example, in [31]. The influence of the structure itself and the applied materials of building partitions on the parameters of the effective insulation and ventilation coefficient are shown in [32].

Table 2. Basic model data used in all simulations.

\begin{tabular}{cc}
\hline Calculation Parameter & Value \\
\hline Time steps per hour & one step \\
Simulation period & from 01.01 to 12.31 of typical calc. year \\
Temperature control & air temperature \\
\hline
\end{tabular}


Table 2. Cont.

\begin{tabular}{cc}
\hline Calculation Parameter & Value \\
\hline General solution algorithm & conduction transfer function \\
Number of model warm-up days & 30 days \\
Location of the site & Poland $/$ Wroclaw $/ \mathrm{N} 51.10^{\circ} \mathrm{E} 17.03^{\circ}$ \\
Weather data & WMO Region 6/POL/Station no. 124240 \\
Terrain type & open \\
\hline
\end{tabular}

Table 3. Fundamental geometry of the building.

\begin{tabular}{cc}
\hline Parameter & Value \\
\hline External dimensions of the building & $36.05 \times 16.65 \mathrm{~m}$ \\
Total floor area & $597.60 \mathrm{~m}^{2}$ \\
Total building volume & $2728.90 \mathrm{~m}^{3}$ \\
Livestock hall area & $236.50 \mathrm{~m}^{2}$ \\
Livestock hall volume & $709.50 \mathrm{~m}^{3}$ \\
Roof type & open gable, 20 degrees \\
Gates & $68.00 \mathrm{~m}^{2}$ \\
Roof glazing area & $13.80 \mathrm{~m}^{2}$ \\
Wall glazing area & quantity: five gates, total area $\mathrm{m}^{2}$ \\
\hline
\end{tabular}

Table 4. Materials used for the constructions and glazing of simulation models.

\begin{tabular}{cccc}
\hline Construction & Manufacturer/Type & $\begin{array}{c}\text { Total Thickness, } \\
\mathbf{m m}\end{array}$ & $\begin{array}{c}\text { U-Value, } \\
\mathbf{W} /\left(\mathbf{m}^{2} \mathbf{K}\right)\end{array}$ \\
\hline External wall & ALFAPANEL/wall panel PU with mounting & 50 & 0.42 \\
Gable roof & ALFAPANEL/ roof panel PU ARGO & 50 & 0.34 \\
Ground floor & / cast concrete & 200 & 2.27 \\
Glazing & ALFAPANEL/multichamber polycarbonate plates & 35 & 1.11 \\
\hline
\end{tabular}

Table 5. Basic HVAC parameters used in all simulations.

\begin{tabular}{cc}
\hline Parameter & Value \\
\hline Heating and cooling installation & none used \\
Ventilation type & mechanical with or without GAHE \\
$0.0^{\circ} \mathrm{C}$ ("winter season") & $3600 \mathrm{~m}^{3} / \mathrm{h}$ \\
Ventilation air volume at external air temperatures lower than & $\left(90 \mathrm{~m}^{3} / \mathrm{cow}\right)$ \\
Ventilation air volume at external air temperatures greater than & $14.000 \mathrm{~m}^{3} / \mathrm{h}$ \\
$0.0^{\circ} \mathrm{C}$ ("summer season”) & $\left(350 \mathrm{~m}^{3} / \mathrm{cow}^{\prime}\right)$ \\
Roof zone fluorescent lighting heat gains & $4.0 \mathrm{~W} / \mathrm{m}^{2}$ \\
Total cow heat production calculated at $20.0^{\circ} \mathrm{C}$ & $1270 \mathrm{~W} / \mathrm{cow}$ \\
Sensible and latent heat-production ratio & depending on the livestock hall indoor temperature \\
Sensible and latent heat-production localization & animal residence zone only \\
Sensible heat-production range MIN/AVERAGE/MAX & $140.4 \mathrm{~W} / \mathrm{m}^{2} / 149.1 \mathrm{~W} / \mathrm{m}^{2} / 156.4 \mathrm{~W} / \mathrm{m}^{2}$ \\
Latent heat-production range MIN/AVERAGE/MAX & $60.7 \mathrm{~W} / \mathrm{m}^{2} / 62.4 \mathrm{~W} / \mathrm{m}^{2} / 64.4 \mathrm{~W} / \mathrm{m}^{2}$
\end{tabular}

The free-stall cowshed was designed for 40 dairy cows (40.00 LSU). A system of keeping animals on a deep litter, a walking and slurry corridor, and a waiting room-on grates. A light-construction building, one-story, without a basement, was built. The object was intended only for dairy cattle breeding. Model simplification: within the building, there was no space for a delivery room and rooms for keeping calves, heifers, and dried cows.

To create most of the EDSL TAS models "construction elements", lightweight materials were used. Low-thickness wall/roof panels and multichamber polycarbonate plates were used because of their easy assembly and the relatively low costs of these types of materials. Details of the "construction elements" are presented in Table 4, Figures 3 and 4. 


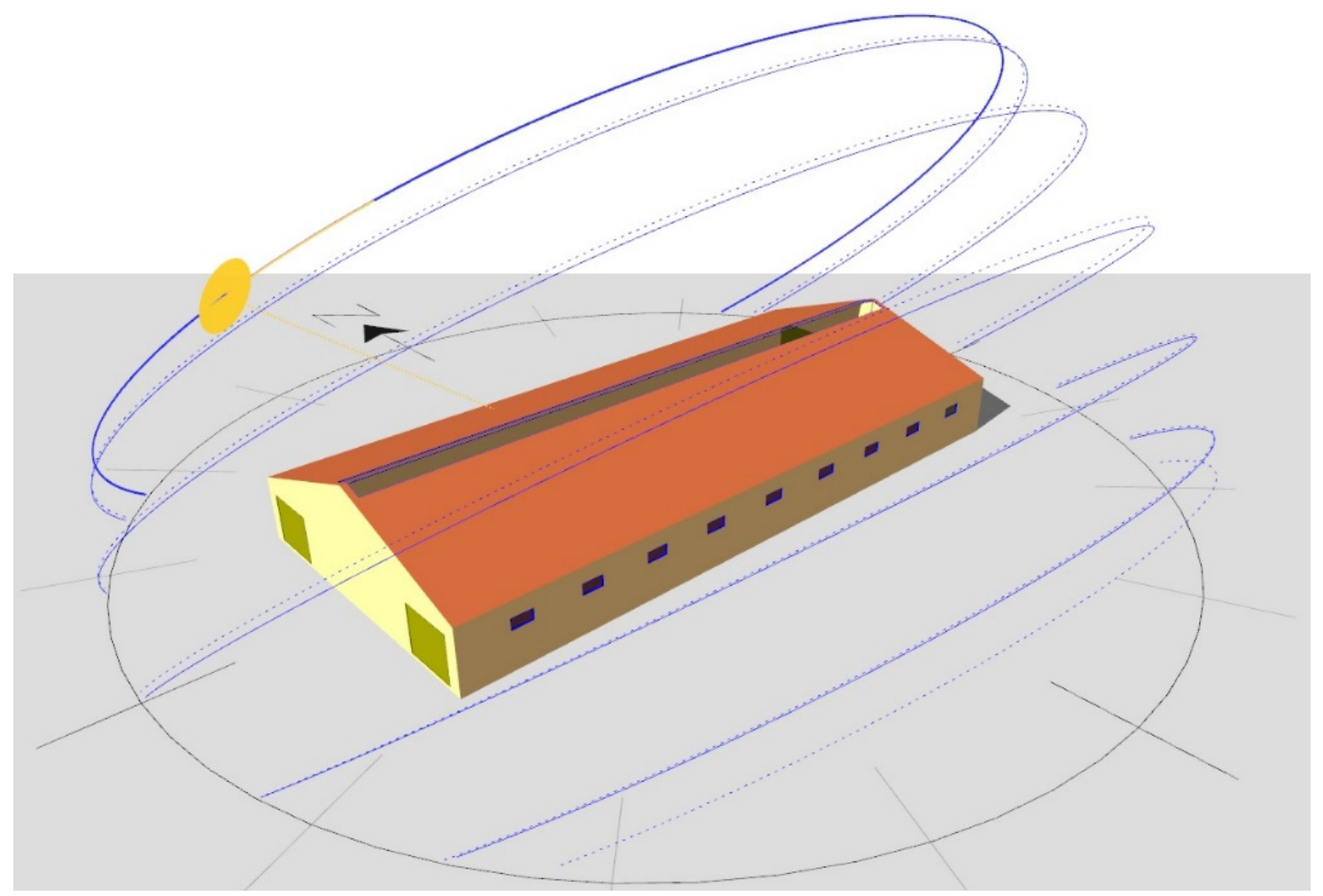

Figure 3. Basic simulation model, S-W angle view, Sun position day 178 at 16:00 h, TAS 3D Modeler.

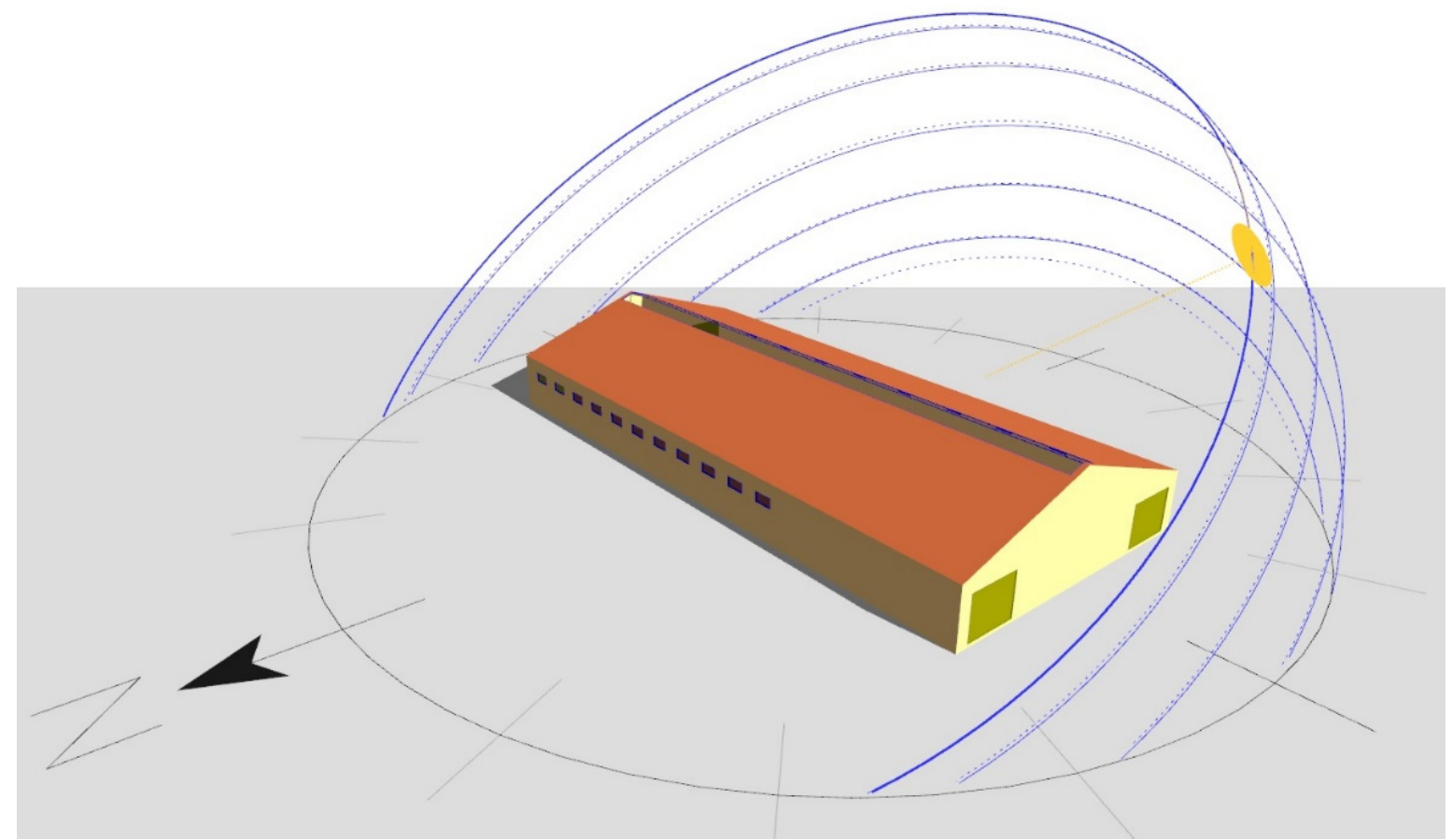

Figure 4. Basic simulation model, N-W angle view, Sun position day 178 at 16:00 h, TAS 3D Modeler.

A very important part of the simulation model is the definition of "internal conditions" for all simulation zones. The parameters necessary in creating "internal conditions" for the simulations of this article are presented in Table 5. Ventilation air volumes were adjusted as a minimum value for the winter (simplification: when external air temperatures are lower than $0.0^{\circ} \mathrm{C}$ ) and summer seasons, as described in [33]. Internal total and sensible and latent heat production were calculated on the basis of formulas 2-4 (mentioned below) 
in accordance with the guidelines presented in [34]. Simplification: diurnal variation in animal heat production was not taken into consideration.

\subsubsection{Total Dairy-Cow Heat Production}

For the calculation of total dairy-cow heat, values of $m=650 \mathrm{~kg}$ of mean body mass and $Y_{1}=25 \mathrm{~kg}$ of milk production were assumed. Due to difficulties considering the calculations of the number of days of pregnancy described in [35], a simplification was assumed-all pregnant cows are moved to a separate building. Due to this fact, the number of days of the pregnancy value $(p)$ was set to 0 days.

Total dairy-cow heat production at a temperature $20.0^{\circ} \mathrm{C}$ was calculated based on the formula [36]:

$$
\Phi_{\text {tot }}=5.6 \cdot m^{0.75}+22 \cdot Y_{1}+1.6 \cdot 10^{-5} \cdot p^{3}
$$

where:

$\Phi_{\text {tot }}$ - total production of milk from dairy-cow heat production at temperature $20.0^{\circ} \mathrm{C}, \mathrm{W}$;

m-body mass of cow, $\mathrm{kg}$;

$Y_{1}$-milk production, $\mathrm{kg}$;

$p$-number of days of pregnancy.

Total dairy-cow heat production at a lower temperature than $20.0{ }^{\circ} \mathrm{C}$ expressed per $h_{p u}$ was calculated on the basis of the formula [34]:

$$
\Phi_{t o t, h_{p u}}=1000+4 \cdot\left(20-t_{l s h}\right)
$$

where:

$\Phi_{t o t, h_{p u}}$-total dairy-cow heat production at temperature different then $20.0^{\circ} \mathrm{C}, \mathrm{W}$;

$t_{l s h}$-livestock room, ${ }^{\circ} \mathrm{C}$;

$h_{p u}$-heat producing unit $\left(1000 \mathrm{~W}\right.$ in total heat at $\left.20.0^{\circ} \mathrm{C}\right)$

\subsubsection{Sensible Dairy-Cow Heat Production}

For the calculation of the value of sensible dairy-cow heat production of the correction factor for sensible heat $k_{s}=0.71$ was assumed (wet feed and wet floors). The influence of wet floors and wet feed on heat production was not further analyzed in detail further.

Sensible dairy-cow heat production at a temperature different from the $20^{\circ} \mathrm{C}$ expressed per $h_{p u}$ was calculated on the basis of the formula [34]:

$$
\Phi_{s, h_{p u}}=k_{s} \cdot \Phi_{t o t, h_{p u}}-0.408 \cdot t_{l s h}^{2}
$$

where:

$\Phi_{s, h_{p u}}$-sensible dairy-cow heat production at a temperature different then $20.0^{\circ} \mathrm{C}, \mathrm{W}$; $k_{s}$ - correction factor for sensible heat.

\subsubsection{Creation of EDSL TAS “Internal Condition” for GAHE}

The "Internal condition" for the GAHE was created by assigning proper minimum and maximum values to GAHE supply air temperatures and relative humidity, for every hour of the entire simulation span. The values used were based on the guidelines of [29].

\subsection{Options Considered and Research Route}

The following describes the assumptions made for each of the variants analyzed:

1. External conditions - the cows are kept outside, Polish second climate zone.

2. Typical case-ventilation air volume at external air temperatures lower than $0{ }^{\circ} \mathrm{C}$ set at $90 \mathrm{~m}^{3} / \mathrm{cow} / \mathrm{h}$, ventilation air volume at external air temperatures higher than $0{ }^{\circ} \mathrm{C}$ set at $350 \mathrm{~m}^{3} / \mathrm{cow} / \mathrm{h}$.

3. Typical case with GAHE-air supplied through GAHE, ventilation air volume at external air temperatures lower than $0^{\circ} \mathrm{C}$ set to $90 \mathrm{~m}^{3} / \mathrm{cow} / \mathrm{h}$, and ventilation air volume at external air temperatures higher than $0{ }^{\circ} \mathrm{C}$ set to $350 \mathrm{~m}^{3} / \mathrm{cow} / \mathrm{h}$. 
4. GAHE, daily average, $0^{\circ} \mathrm{C}$-air supplied through $\mathrm{GAHE}$, ventilation air volume at daily average external air temperatures lower than $0{ }^{\circ} \mathrm{C}$ set at $90 \mathrm{~m}^{3} / \mathrm{cow} / \mathrm{h}$, and ventilation air volume at daily average external air temperatures higher than $0{ }^{\circ} \mathrm{C}$ set at $350 \mathrm{~m}^{3} / \mathrm{cow} / \mathrm{h}$, setting the mode of operation for the next $24 \mathrm{~h}$ at 6 a.m.-after morning milking.

5. GAHE, daily average, $6 / 8^{\circ} \mathrm{C}$-air supplied through GAHE, ventilation air volume at daily average external air temperatures lower than $6^{\circ} \mathrm{C}$, throughout the year, $90 \mathrm{~m}^{3} / \mathrm{cow} / \mathrm{h}$, and ventilation air volume at daily average external air temperatures higher than $8{ }^{\circ} \mathrm{C}$ set at $350 \mathrm{~m}^{3} / \mathrm{cow} / \mathrm{h}$, setting the mode of operation for the next $24 \mathrm{~h}$ at 6 a.m.- -after morning milking.

6. GAHE, throughout the year, $90 \mathrm{~m}^{3} / \mathrm{cow} / \mathrm{h}$-air supplied through the GAHE, and ventilation air volume set to a constant value of $90 \mathrm{~m}^{3} / \mathrm{cow} / \mathrm{h}$ throughout the year.

7. GAHE, throughout the year, $350 \mathrm{~m}^{3} / \mathrm{cow} / \mathrm{h}$-air supplied through GAHE, and ventilation air volume set to constant value of $350 \mathrm{~m}^{3} / \mathrm{cow} / \mathrm{h}$ throughout the year.

8. GAHE, throughout the year, $180 \mathrm{~m}^{3} / \mathrm{cow} / \mathrm{h}$ - air supplied through the GAHE, and ventilation air volume set to a constant value of $180 \mathrm{~m}^{3} / \mathrm{cow} / \mathrm{h}$ throughout the year.

9. GAHE, throughout the year, $270 \mathrm{~m}^{3} / \mathrm{cow} / \mathrm{h}$ - air supplied through the GAHE, and ventilation air volume set to constant value of $270 \mathrm{~m}^{3} / \mathrm{cow} / \mathrm{h}$ throughout the year.

10. GAHE, daily average, $6 / 8{ }^{\circ} \mathrm{C}, 180 / 270 \mathrm{~m}^{3} / \mathrm{cow} / \mathrm{h}$-air supplied through GAHE, ventilation air volume at daily average external air temperatures lower than $6{ }^{\circ} \mathrm{C}$ set to $180 \mathrm{~m}^{3} / \mathrm{cow} / \mathrm{h}$, and ventilation air volume at daily average external air temperatures higher than $8{ }^{\circ} \mathrm{C}$ set to $270 \mathrm{~m}^{3} / \mathrm{cow} / \mathrm{h}$, setting the mode of operation for the next $24 \mathrm{~h}$ at 6 a.m.--after morning milking.

The range of minimum $\left(90 \mathrm{~m}^{3} / \mathrm{cow} / \mathrm{h}\right) /$ maximum $\left(350 \mathrm{~m}^{3} / \mathrm{cow} / \mathrm{h}\right)$ air-volume supply was adopted based on [3], described in Table 1.

For Variants 4 and 9 , the lower switching point $\left(6^{\circ} \mathrm{C}\right)$ was determined based on the minimum allowable temperature recommended for cows (Table 1), and the upper switching point $\left(8^{\circ} \mathrm{C}\right)$ was determined based on the lower limit of the optimal temperature range recommended for cows (Table 1 ).

\section{Results and Discussion}

The results of the simulation model of the analyzed building are presented below.

\subsection{Results of Calculations and Analysis}

Calculations of parameters in the analyzed barn were made for the nine operation variants of the ventilation system described above. The results calculated for the zero variant show the conditions under which the cows would stay outside the barn in the moderate climate of Wroclaw.

For Variant 0 , the outside air temperature varied from -18.8 to $31.3{ }^{\circ} \mathrm{C}$. Relative humidity ranged from 26.0 to $100.0 \%$. The THI index ranged from 4.2 to 78.7 , and its average annual value was 47.2 . The largest daily temperature fluctuation was at $19 \mathrm{~K}$ and the annual daily average outside air temperature was at $8.0 \mathrm{~K}$.

For Variant 1, the indoor air temperature varied from 6.0 to $32.8^{\circ} \mathrm{C}$. Relative humidity ranged from 33.1 to $99.7 \%$. The THI index ranged from 42.8 to 81.5 and its average annual value was 66.0. The largest daily fluctuation of temperature was $15.5 \mathrm{~K}$, and the annual daily average outside air temperature was $7.3 \mathrm{~K}$. This is consistent with the information provided in publications [37,38]. In Variant 1 (Figures 5-7), when the room is ventilated directly using outside air, with different air volumes for warm and cold periods, with a mode switch at a temperature of $0.0^{\circ} \mathrm{C}$ (based on the assumption, that during a cold period the air temperature in the cowshed should be a maximum of 10 degrees higher than outdoors and 10 degrees lower during warm period), the results obtained often exceeded the appropriate thermal and humidity conditions for cows, both in winter and summer. 


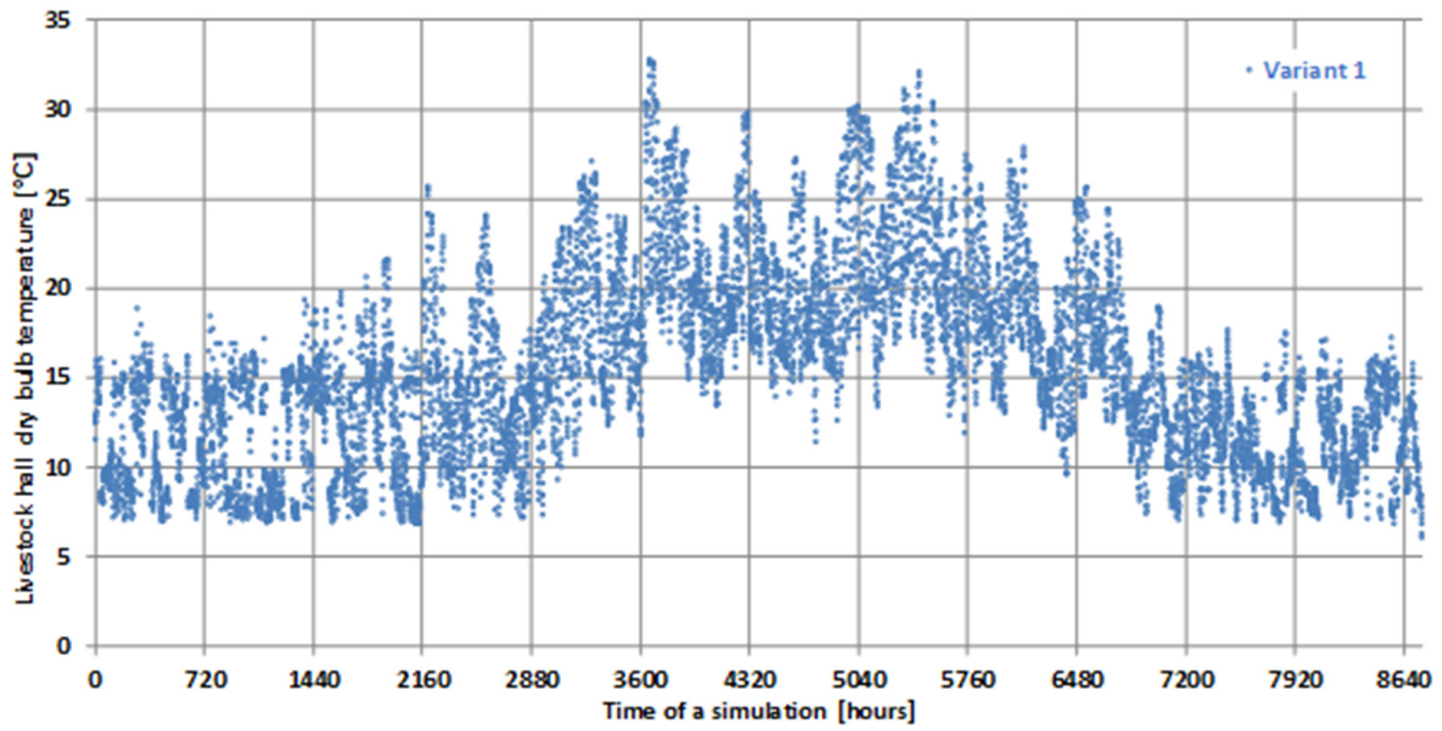

Figure 5. The course of changes in air temperature in the animal residence zone-Variant 1.

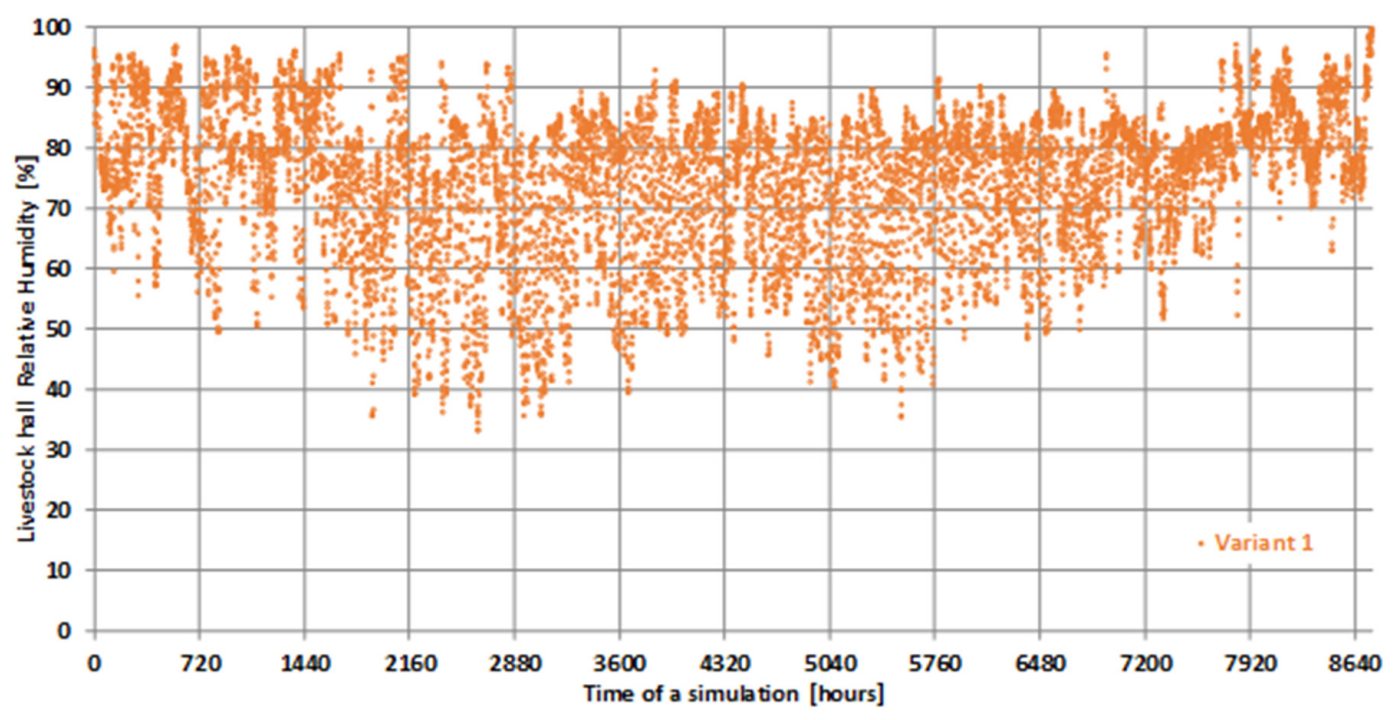

Figure 6. The course of air humidity in the animal residence zone-Variant 1.

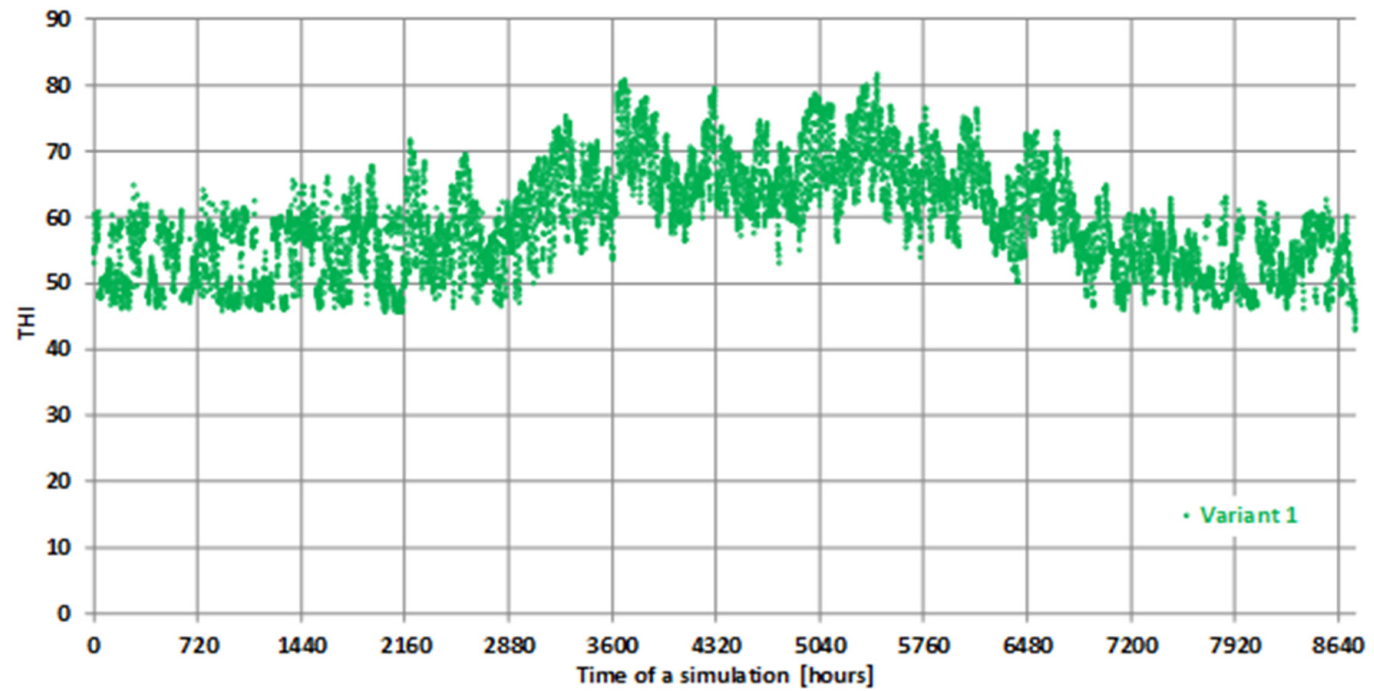

Figure 7. The course of changes in the THI index in the animal residence zone-Variant 1. 
Additionally, large fluctuations in internal air temperatures were recorded in the winter season. During winter days, air in the barn was cooled below $10.0^{\circ} \mathrm{C}$, despite the ventilation air volume limited to the minimum value of $90 \mathrm{~m}^{3} / \mathrm{cow} / \mathrm{h}$. Especially during the winter season, high variability and maximum values of relative air humidity were noted. Low temperatures on the internal surfaces of the walls and roof with the addition of high relative air humidity can lead to significant condensation of moisture on the surface of these partitions.

However, during the summer period, significant and frequent exceedances of the air temperature in the barn can be observed above the recommended maximum value of $25.0^{\circ} \mathrm{C}$. The THI index values in the summer period exceeded stress conditions in many cases. Cases described above appeared despite the use of the highest recommended air flow of $350 \mathrm{~m}^{3} /$ cow $/ \mathrm{h}$.

\subsubsection{Application of GAHE}

For Variant 2, the indoor air temperature varied from $9.0^{\circ} \mathrm{C}$ to $23.0^{\circ} \mathrm{C}$. Relative humidity ranged from 39.7 to $95.2 \%$. The THI index ranged from 50.3 to 72.5 , and its average annual value was 60.3 . The highest fluctuation in daily temperature was $13.0 \mathrm{~K}$, and the annual average outside air temperature was $3.3 \mathrm{~K}$.

The simulations of the operation of Variant 2 (Figures 8-10) were based on the same assumptions as Variant 1. The only difference was the use of the GAHE exchanger in the system shown in Figure 2c. Pretreatment of the air in the exchanger reduced the occurrence of excessively high temperatures in the animal residence zone during the warm period and also resulted in a significant reduction between daily temperature and humidity fluctuations during the cold period. Despite the improvement, the results did not meet the desired requirements. Conclusions drawn from the analysis of the results of Variant 2 were the basis for the correction of the method of controlling the operation of the GAHE-assisted ventilation system.

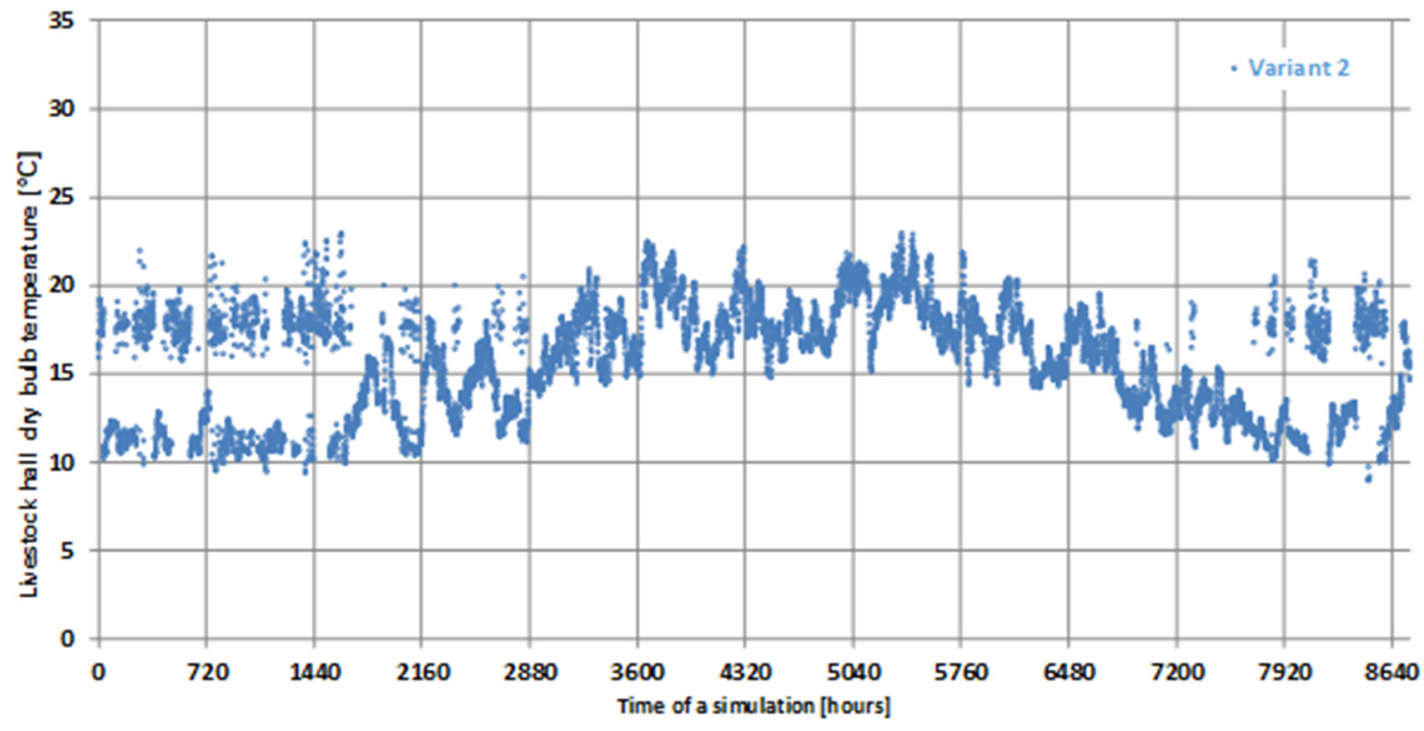

Figure 8. The course of changes in air temperature in the animal residence zone-Variant 2.

3.1.2. Limitation of the Minimum and Maximum Values of Air Temperature and Humidity in the Barn-Variants 3 and 4-Change in Ventilation-Control Method

For Variant 3 (Figures 11-13), the indoor air temperature varied from 8.4 to $23.0^{\circ} \mathrm{C}$. Relative humidity ranged from 39.4 to $95.2 \%$. The THI index ranged from 50.0 to 72.5 , and its average annual value was 60.3 . The highest fluctuation in daily temperature was $11.7 \mathrm{~K}$, and the average annual outside air temperature was $2.6 \mathrm{~K}$. 


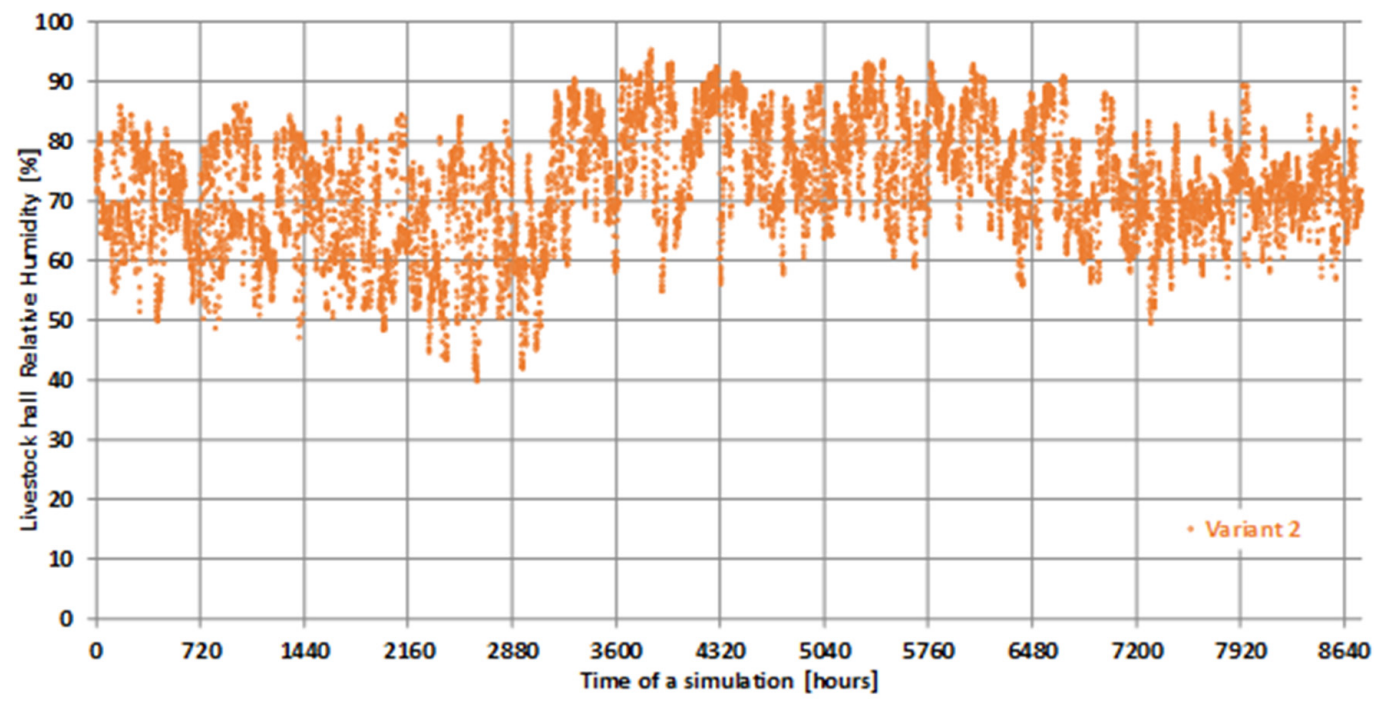

Figure 9. The course of air humidity in the animal residence zone-Variant 2.

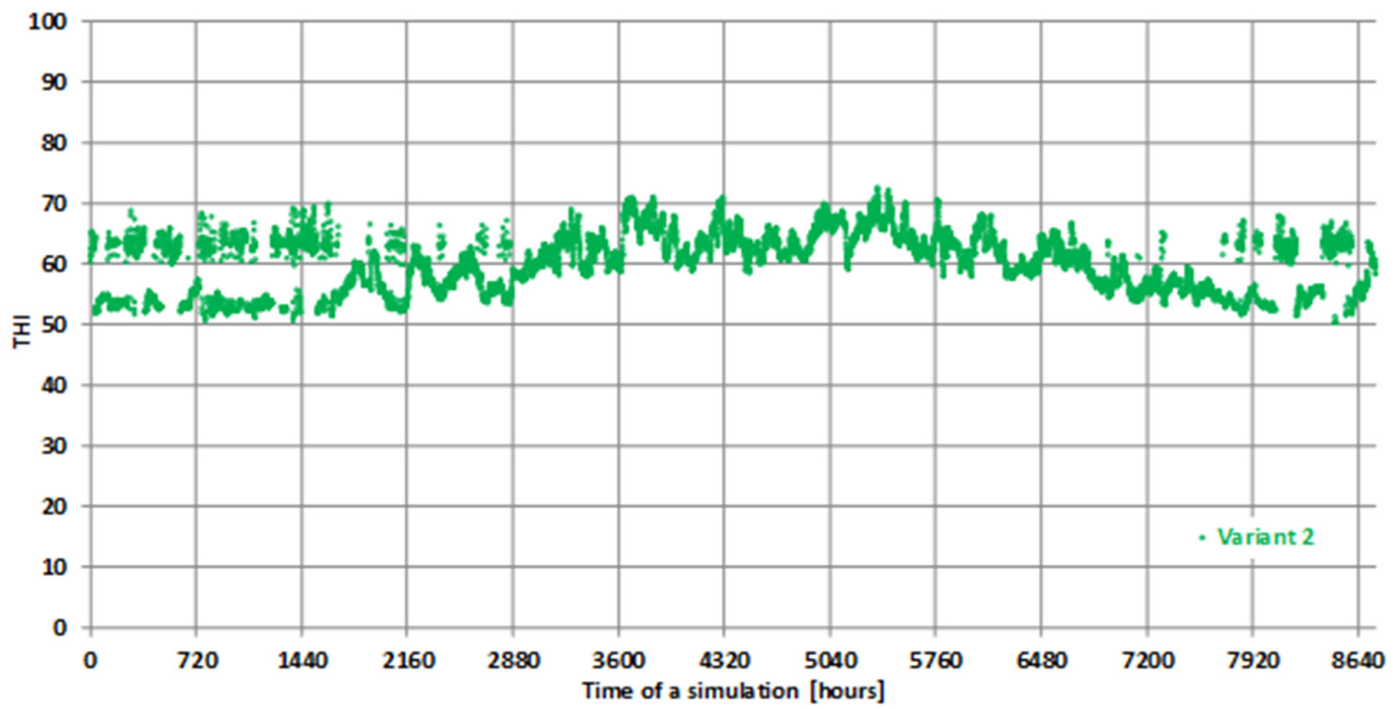

Figure 10. The course of changes in the THI index in the animal residence zone-Variant 2.

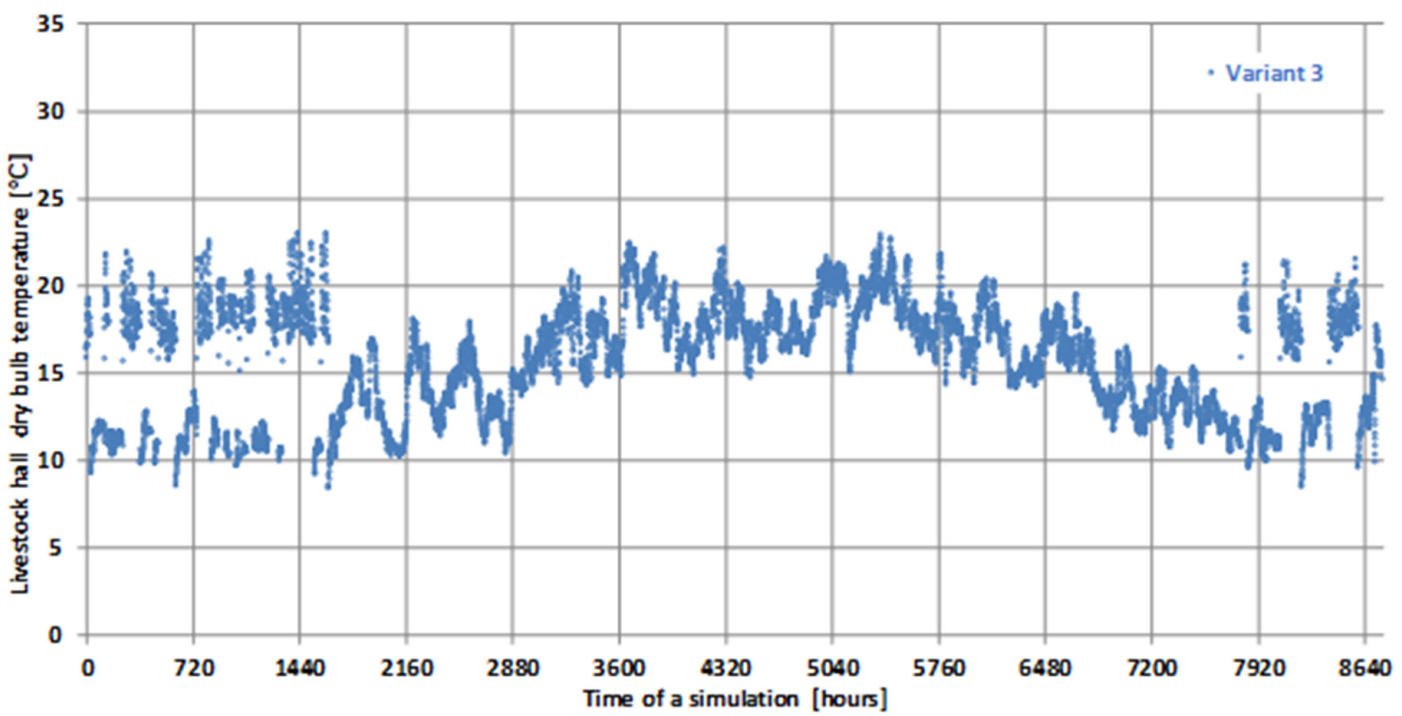

Figure 11. The course of air-temperature changes in the animal residence zone-Variant 3. 


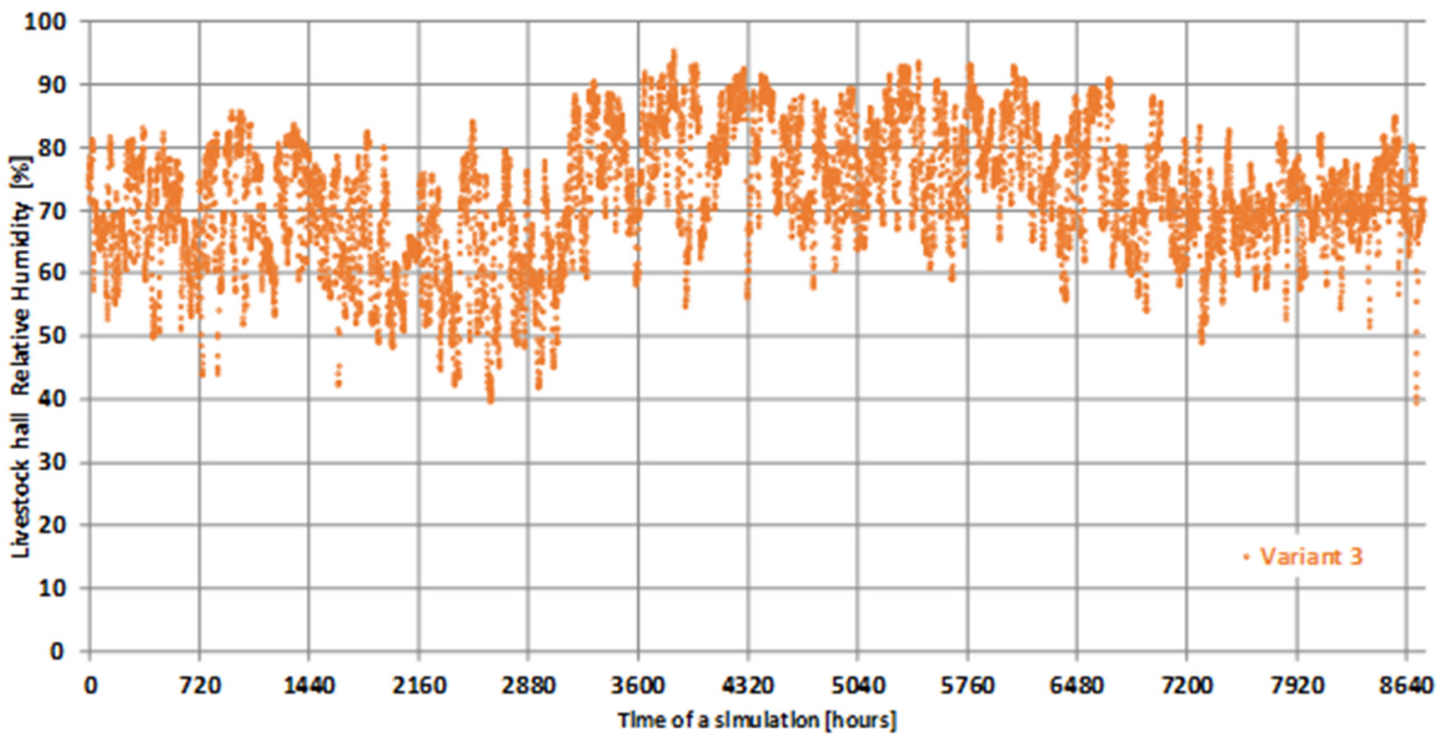

Figure 12. The course of changes in air humidity in the animal residence zone-Variant 3.

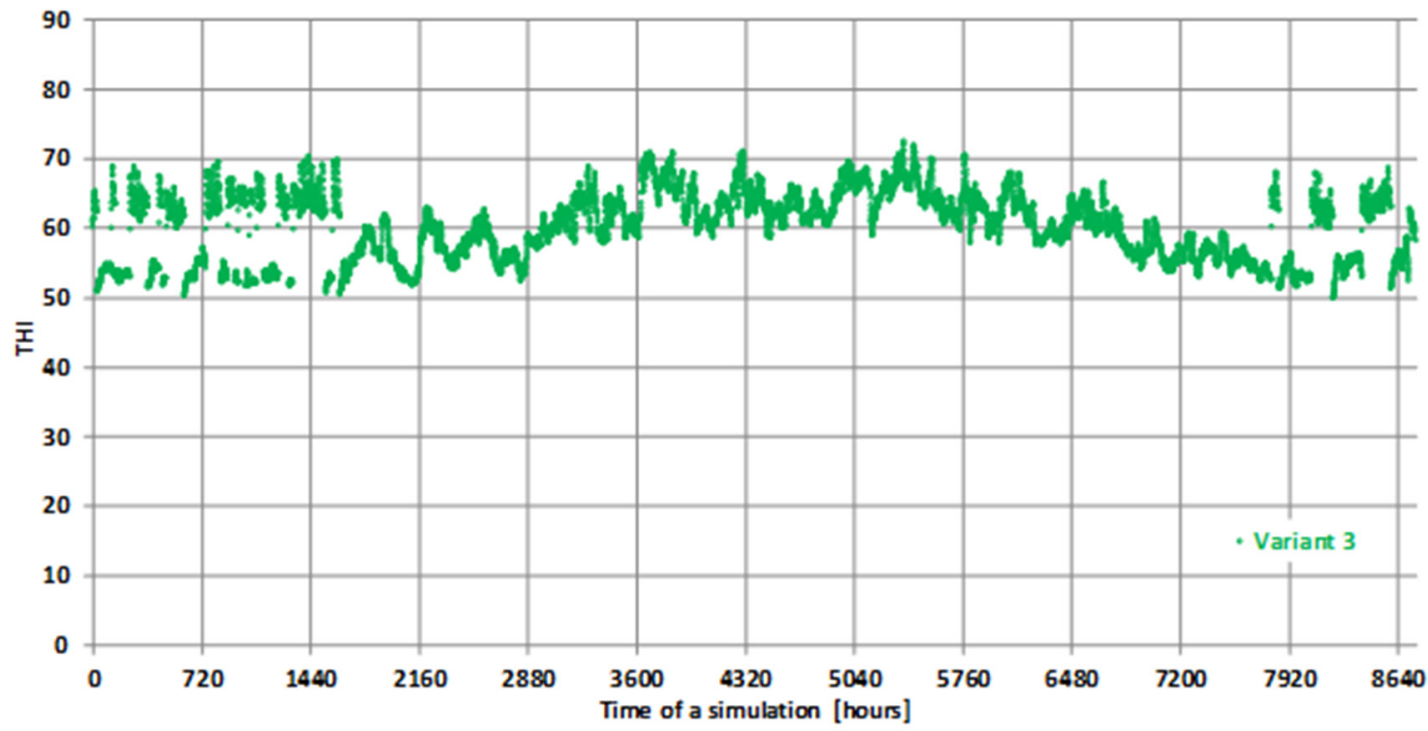

Figure 13. The course of changes in THI index in the animal residence zone-Variant 3.

In the simulations of Variant 3 (ventilation air volume depended on the average daily temperature of the outside air, setpoint at $0.0^{\circ} \mathrm{C}$ ) the occurrences of fluctuations in air temperature in the animal residence zone during the transition period were limited, but the same did not occur during the cold period. The values of the THI index generally did not exceed the cow-stress limit. However, no satisfactory improvement in the barn microclimate parameters was achieved during the cold period (there is still a large daily variability in internal temperature).

For Variant 4 , the indoor air temperature varied from 11.1 to $23.6^{\circ} \mathrm{C}$. Relative humidity ranged from 39.7 to $96.7 \%$. The THI index ranged from 53.5 to 72.5 , and its average annual value was 64.0. The highest fluctuation in daily temperature was $10.2 \mathrm{~K}$, and the annual average outside air temperature was $2.6 \mathrm{~K}$.

In the simulations of Variant 4 (ventilation air volume depended on two different set points of the average daily temperature of the outside air, set points at 6 and $8^{\circ} \mathrm{C}$ ), a significant reduction in daily fluctuations and an overall increase in the air temperature of the animal residence zone were achieved during the cold period, all without a significant increase in the values of the rest of the parameters' values. Higher day-to-day variability occurred only in the transition period. 
The result of the simulations of Variants 3 and 4 was the achievement of the intended goal-a significant reduction in day-to-day temperature and humidity fluctuations. Unfortunately, the changes introduced resulted in an overall increase in the average air temperature in the cowshed, which contributed to multiple exceedances of the upper limit of the THI index.

To determine the method of controlled reduction in air temperature in the cowshed, further simulations were carried out taking into account changes in the amount of external air.

3.1.3. Limitation of the Minimum and Maximum Values of Air Temperature and Humidity in the Barn-Variant 5-8-Change in Ventilation Air Volumes

In Variants 5, 6, 7, and 8 (Figures 14-16 show results for the extreme cases of minimum and maximum ventilation air volumes, i.e., Variants 5 and 6), the possibilities of using deferent constant ventilation air volumes throughout the year had been analyzed.

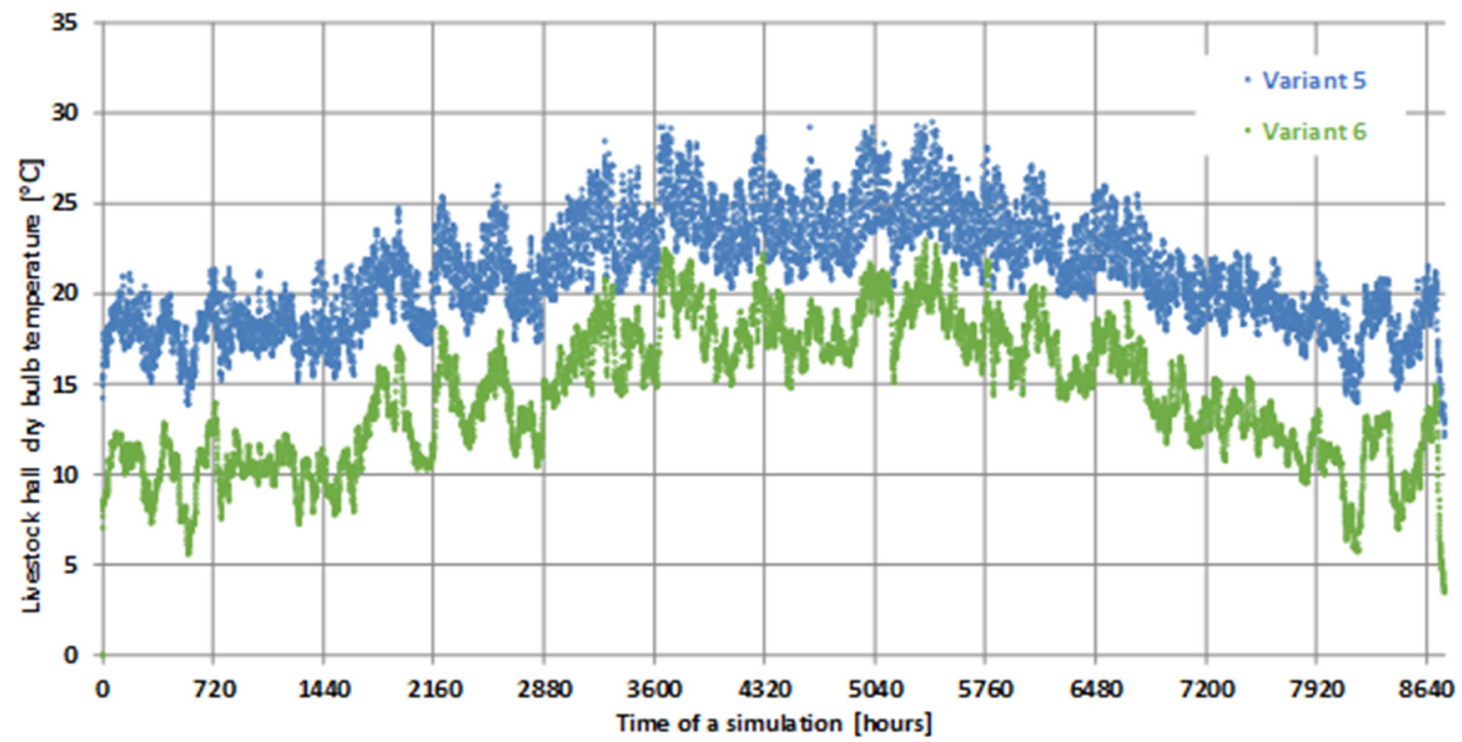

Figure 14. The course of air temperature changes in the animal residence zone-Variants 5 and 6.

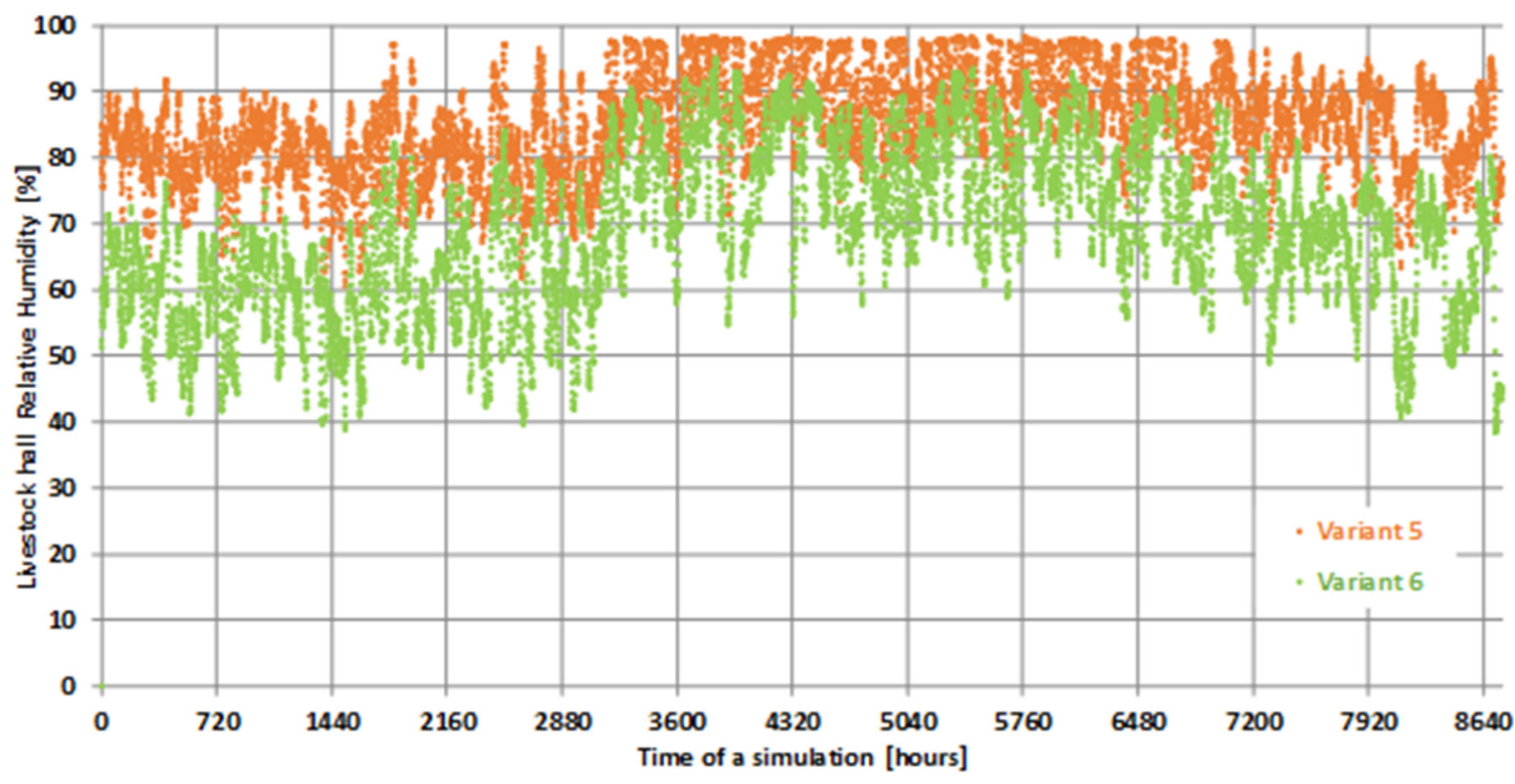

Figure 15. The course of air humidity in the animal residence zone-Variants 5 and 6. 


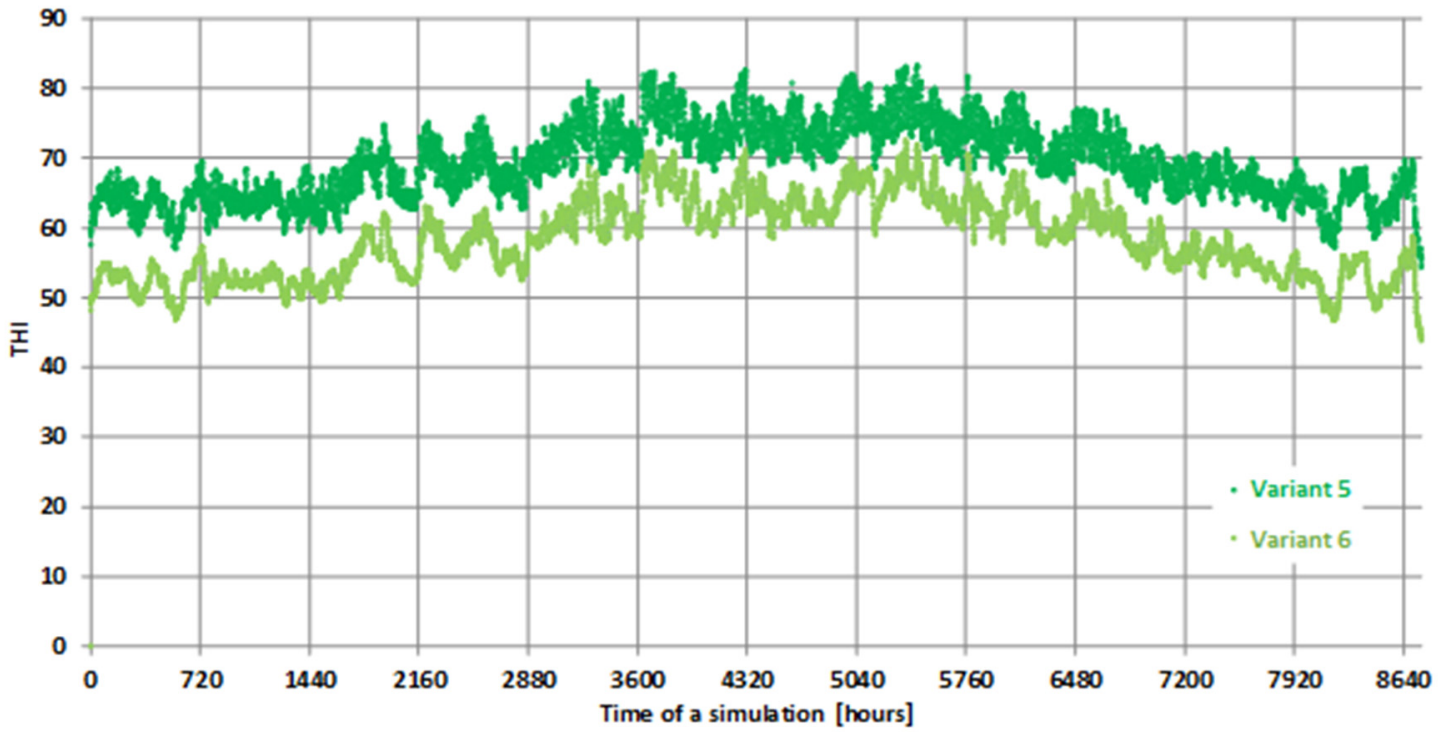

Figure 16. The course of changes in the THI index in the animal residence zone-Variants 5 and 6.

In Variant 5, due to the significant limitation of ventilation air volume during the warm period, the thermal comfort conditions in the animal residence zone were significantly exceeded. However, in the cold period, the conditions in that zone were within the recommended limits.

In Variant 6 (constant maximum ventilation air volume throughout the year), despite the use of GAHE, high drops in the air-temperature values of the animal residence zone were observed at the lowest temperatures of the outside air. On the other hand, during the warm period, the temperature conditions and the THI index values almost did not exceed the recommended values.

In the simulations of Variants 7 and 8, the microclimate conditions of the barn were analyzed, assuming the use of intermediate ventilation air volumes, constant for the entire simulation period. The increase in the minimum air volume (Variant 7) contributed to the improvement in internal conditions that occurred during the cold period. On the other hand, the partial limitation of the maximum air volume (Variant 8) during the warm period only slightly worsened the results obtained from the air temperatures in the animal residence zone. The results obtained suggested the validity of a selective combination of the described ventilation methods, i.e., the usage of an increased air volume for the cold period and a partially reduced air volume for the warm period. On this basis, the simulation model of Variant 9 was created.

\subsubsection{Final Variant for the Adopted Assumptions}

Selected assumptions from Variants 4, 7, and 8, those that improved the obtained results, were combined in the proposed control method of the ventilation system supported with the GAHE exchanger and were used in the Variant 9 simulation model. For this method of control, in the animal residence zone, satisfactory air temperature and humidity values were obtained throughout the year and a significant reduction in the variability of indoor air temperature was achieved. At the same time, the THI index values exceeded the established limits in only a few cases.

For Variant 9 (Figures 17-19) the indoor air temperature varied from 8.9 to $23.9{ }^{\circ} \mathrm{C}$. Relative humidity ranged from 42.4 to $95.9 \%$. The THI index ranged from 50.7 to 74.0 , and its average annual value was 61.8. The highest fluctuation in daily temperature was $5.2 \mathrm{~K}$, and the annual average outside air temperature was $2.1 \mathrm{~K}$. 


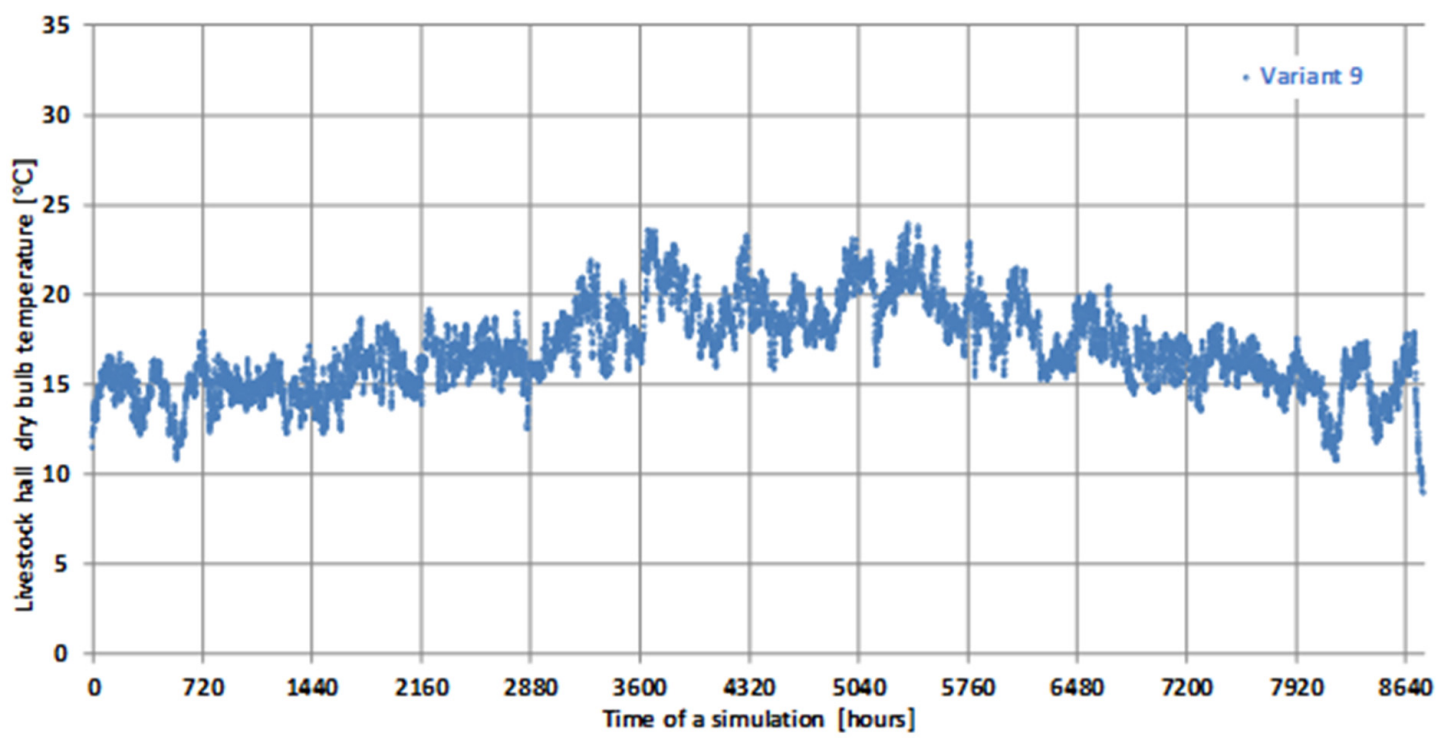

Figure 17. The course of air-temperature changes in the animal residence zone-Variant 9.

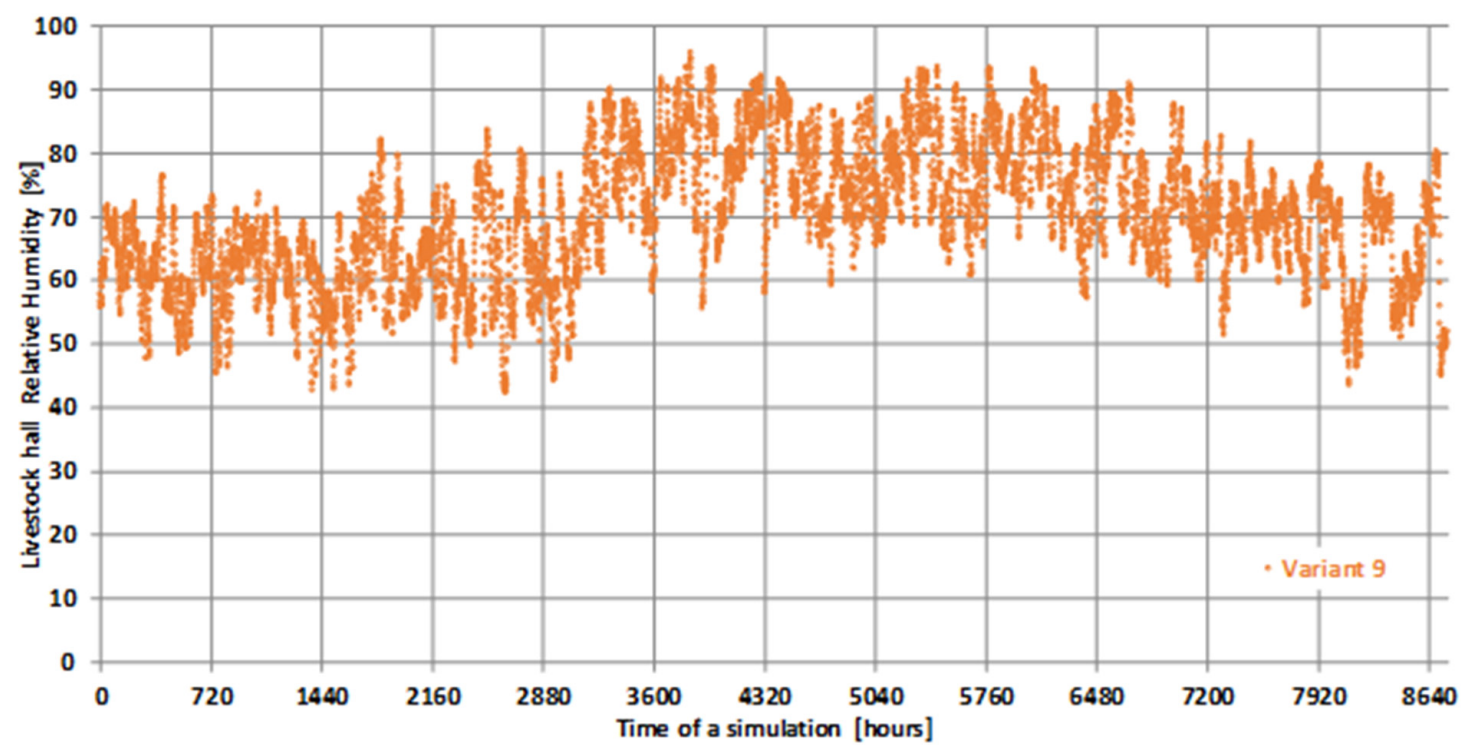

Figure 18. The course of air-humidity changes in the animal residence zone-Variant 9.

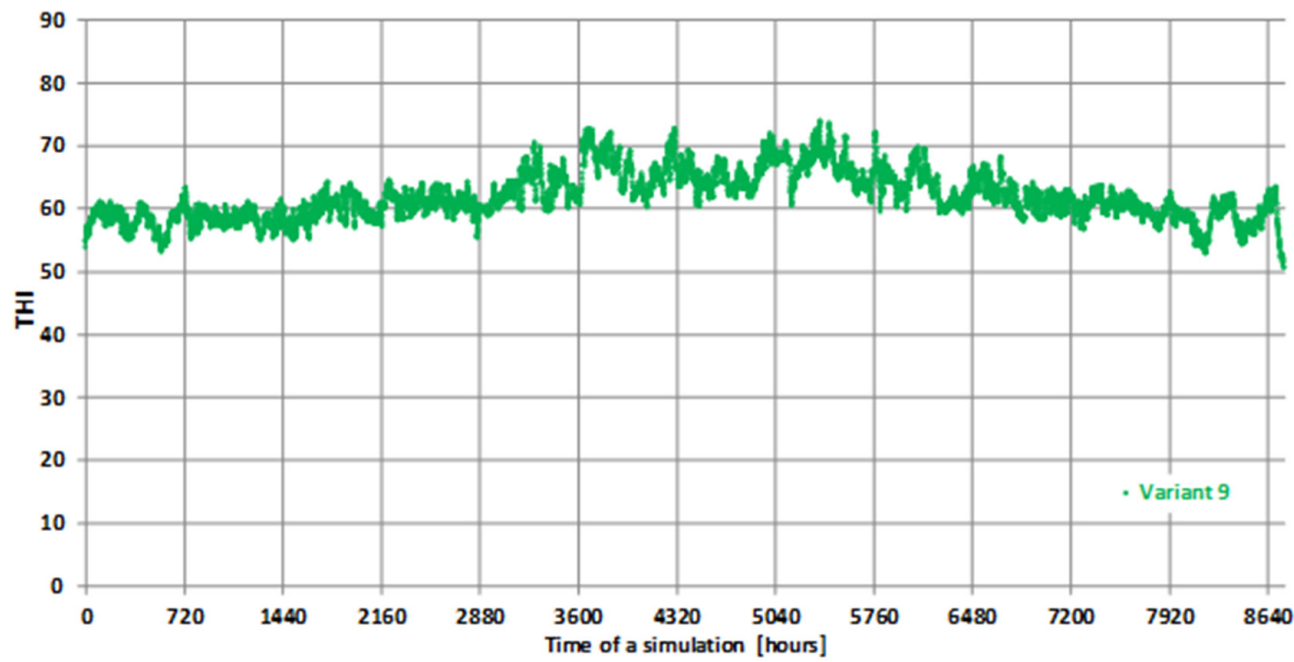

Figure 19. The course of changes in THI index in the animal residence zone-Variant 9. 
A comparison of the average daily changes in air temperature in the animal residence zone for Variant 1, Variant 2, and Variant 9 is shown in Figure 20. In the classic variant (Variant 1) and even in variant with GAHE (Variant 2), the fluctuations were large and could reach even $15.0 \mathrm{~K}$. In the proposed solution, daily temperature fluctuations did not exceed $5.0 \mathrm{~K}$, and the annual daily average was $2.1 \mathrm{~K}$, compared to $7.3 \mathrm{~K}$ for Variants 1 and $3.3 \mathrm{~K}$ for Variant 2. In Variant 2, large fluctuations occurred in the cold period, whereas in the warm period they were similar to the fluctuations of Variant 9.

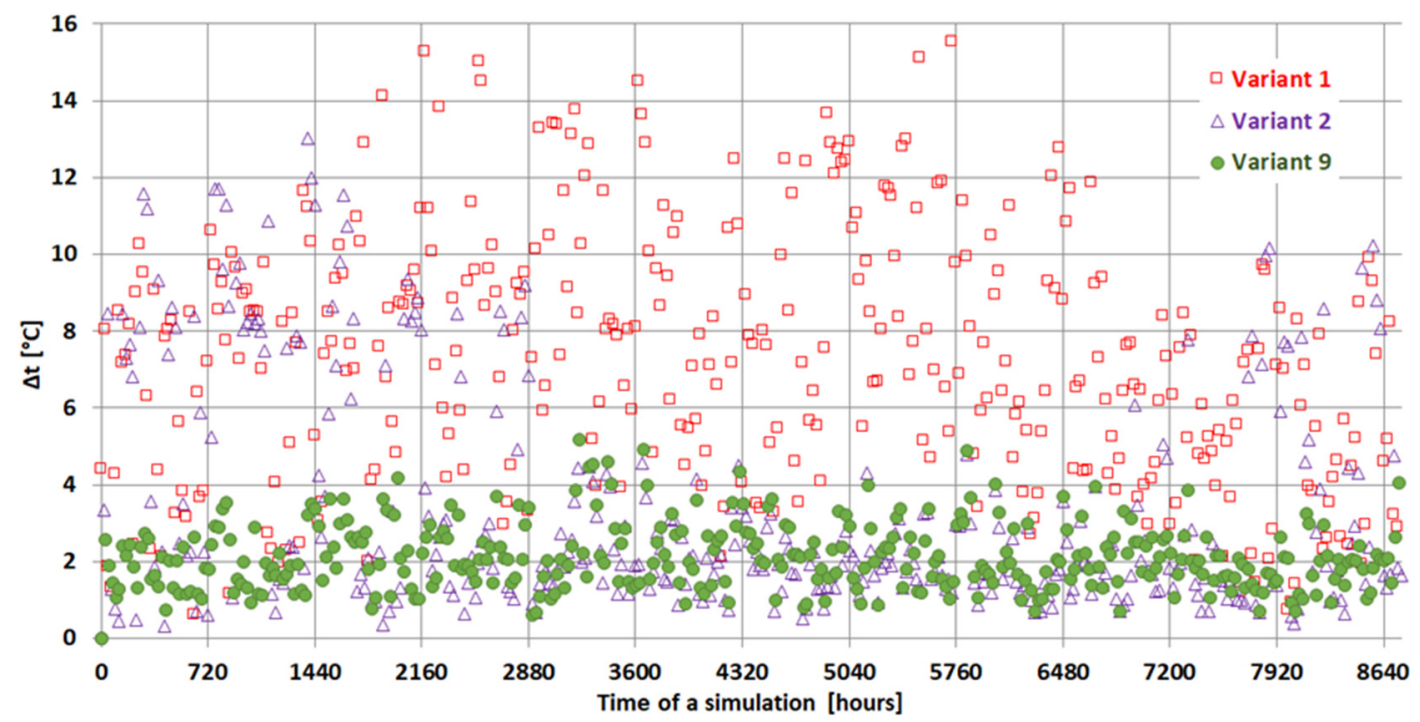

Figure 20. Changes in maximum daily temperature.

\subsection{Comparison of Variants}

The summary of the calculation and simulation results for individual variants are shown in Tables 6 and 7.

Table 6. Time of occurrence of temperature and relative humidity exceedances, and maximum and average daily temperature changes for all analyzed variants, hours.

\begin{tabular}{|c|c|c|c|c|c|c|c|c|c|c|c|c|}
\hline Variant & & & Temperatur & & & & tive Humi & & Both & Both & $\operatorname{Max} \Delta t$ & $\operatorname{Avg} \Delta t$ \\
\hline- & $\mathrm{t}<8^{\circ} \mathrm{C}$ & $t>16^{\circ} \mathrm{C}$ & $\mathrm{t}>20^{\circ} \mathrm{C}$ & $\mathrm{t}<6^{\circ} \mathrm{C}$ & $\mathrm{t}>25^{\circ} \mathrm{C}$ & $\varphi<60 \%$ & $\varphi>80 \%$ & $\varphi>85 \%$ & $\begin{array}{l}16<\mathrm{t}<8^{\circ} \mathrm{C} \& \\
80<\varphi<60 \%\end{array}$ & $\begin{array}{l}20<\mathrm{t}<8^{\circ} \mathrm{C} \& \\
80<\varphi<60 \%\end{array}$ & $\mathbf{K}$ & $\mathbf{K}$ \\
\hline 0 & 4332 & 1617 & 699 & 3706 & 175 & 1154 & 4957 & 3779 & 4274 & 3832 & 19.0 & 8.0 \\
\hline 1 & 481 & 3529 & 1706 & 0 & 462 & 1293 & 3221 & 1420 & 1933 & 1077 & 15.5 & 7.3 \\
\hline 2 & 0 & 4735 & 598 & 0 & 0 & 976 & 2089 & 1032 & 2051 & 357 & 13.0 & 3.3 \\
\hline 3 & 0 & 4627 & 685 & 0 & 0 & 1116 & 2027 & 1007 & 1979 & 356 & 11.7 & 2.6 \\
\hline 4 & 0 & 7335 & 1648 & 0 & 0 & 410 & 3797 & 1933 & 3760 & 837 & 10.2 & 2.6 \\
\hline 5 & 0 & 8487 & 5292 & 0 & 1043 & 0 & 6747 & 4718 & 6701 & 4467 & 7.8 & 3.5 \\
\hline 6 & 296 & 3357 & 540 & 57 & 0 & 2144 & 1807 & 1005 & 2049 & 647 & 6.3 & 1.8 \\
\hline 7 & 5 & 5550 & 2444 & 0 & 34 & 1157 & 1846 & 878 & 2138 & 1278 & 5.8 & 2.4 \\
\hline 8 & 87 & 4151 & 1015 & 13 & 0 & 1925 & 1675 & 821 & 1924 & 704 & 5.9 & 1.9 \\
\hline 9 & 0 & 5336 & 1014 & 0 & 0 & 1617 & 1672 & 820 & 2071 & 611 & 5.2 & 2.1 \\
\hline
\end{tabular}

Tables 6 and 7 show the distribution of humidity, temperatures, and the THI index in individual ranges calculated for all analyzed variants.

Calculations were made for the entire climatic year $(8760 \mathrm{~h})$ assuming the official climatic data of Wroclaw.

Moving cows from external conditions (Variant 0 ) to a classically ventilated barn (Variant 1) increased the number of hours with unfavorable temperature and humidity values during the warm season. Alarm conditions for the THI index occurred during $2.4 \%$ of the simulation time. The possibility of the occurrence of hazardous conditions was found to be very small (THI 79-84). In the conditions of the cold period, the number of occurrences of low air temperatures was relatively small. 
Table 7. Summary of THI occurrence time for all analyzed variants, hours.

\begin{tabular}{|c|c|c|c|c|c|c|c|c|}
\hline Variant & & & & THI & & & & \\
\hline- & THI $<45$ & THI $>68$ & $68>$ THI $>72$ & $72>$ THI $>75$ & $75>$ THI $>79$ & $79>$ THI $>84$ & THI > 84 & $\begin{array}{c}\text { Avg } \\
\text { Value }\end{array}$ \\
\hline 0 & 3866 & 476 & 306 & 125 & 45 & 0 & 0 & 47.3 \\
\hline 1 & 4 & 1283 & 710 & 329 & 212 & 32 & 0 & 59.2 \\
\hline 2 & 0 & 318 & 314 & 4 & 0 & 0 & 0 & 60.3 \\
\hline 3 & 0 & 351 & 348 & 3 & 0 & 0 & 0 & 60.3 \\
\hline 4 & 0 & 934 & 931 & 3 & 0 & 0 & 0 & 64.0 \\
\hline 5 & 0 & 4859 & 2046 & 1424 & 1094 & 295 & 0 & 69.2 \\
\hline 6 & 9 & 298 & 295 & 3 & 0 & 0 & 0 & 58.3 \\
\hline 7 & 0 & 1818 & 1422 & 351 & 45 & 0 & 0 & 63.1 \\
\hline 8 & 0 & 694 & 660 & 34 & 0 & 0 & 0 & 60.0 \\
\hline 9 & 0 & 692 & 652 & 40 & 0 & 0 & 0 & 61.8 \\
\hline
\end{tabular}

The use of the GAHE exchanger in the simplest version of the ventilation operation control (Variant 2) resulted in a significant improvement of the microclimate in the animal residence zone. The number of hours with low air temperature was limited and air temperature exceedances above the limit of $25.0{ }^{\circ} \mathrm{C}$ were eliminated. THI index values greater than 68 were practically non-existent (3.6\% of the time) and caused mild discomfort at best. Periods of excessive air humidity in the room were also shortened. Relative air humidity above $80.0 \%$ occurred only $23.8 \%$ of the time and above $85.0 \%$ during $11.8 \%$ of the time.

Controlling the operation of the ventilation system operation control based on the average daily temperature of the outside air (Variants 3,4 ) resulted in a slight increase in the air temperature and humidity values in the animal residence zone. Humidity above $85.0 \%$ occurred $22.1 \%$ of the time. There were virtually no discomfort or alarm conditions (THI > 72).

As expected, reduction in the ventilation air volume to the minimum throughout the year (Variant 5) resulted in the desired increase in air temperature in the animal residence zone during the cold period but caused overheating of the zone during the warm period. Inside air temperatures above $25.0{ }^{\circ} \mathrm{C}$ were observed $11.9 \%$ of the time. In contrast, air humidity exceeded $85.0 \% 53.9 \%$ of the time. The THI index values dangerous to animals occurred $3.4 \%$ of the time.

The opposite effect, drop in the temperature and humidity of the internal air values, caused an increase in the ventilation air volume to the maximum value (Variant 5). Temperatures with values less than $8.0{ }^{\circ} \mathrm{C}$ occurred $3.4 \%$ of the time. Practically no uncomfortable values of the THI index occurred ( $68<\mathrm{THI}<72$ in $3.4 \%$ of the time).

The use of intermediate ventilation air volumes (Variants 7 and 8) resulted in the elimination of or significant reduction in unfavorable conditions in the cold (Variant 7) and warm (Variant 8) periods, respectively.

In the final simulation (Variant 9) in the ventilation system, the GAHE exchanger was used. An increased minimum ventilation air volume was established in the cold period $\left(180 \mathrm{dm}^{3} /\right.$ cow $\left./ \mathrm{h}\right)$ and a limited maximum air volume $\left(270 \mathrm{dm}^{3} / \mathrm{cow} / \mathrm{h}\right)$ in the warm period, and the system was controlled on the basis of the average daily temperature of the previous day. Satisfactory indoor air temperature and humidity conditions were obtained throughout the year. Despite the reduced air flow during the warm period, there were no stress conditions in the cowshed, the higher THI values in the range of 68-72 occurred only $7.4 \%$ of the time. The air temperature in the animal residence zone did not rise above $25.0^{\circ} \mathrm{C}$ during any hour. Relative air humidity with a value above $85.0 \%$ in the zone occurred $9.4 \%$ of the time. 


\section{Conclusions}

There are few data describing solutions that use GAHE exchangers for the needs of dairy farming. The quality and quantity of ventilation air supplied to the animal residence zone have a significant impact on the microclimate conditions established inside. Commonly used systems supply air with little or no treatment. The regulation is usually limited to switching the ventilation air stream between the summer and winter volume. Such solutions lead to the frequent occurrence of conditions of discomfort for animals. This phenomenon occurs especially in zones of warm and moderate climate. The use of more extensive ventilation air-treatment systems usually generates significantly higher investment and operating costs. The use of GAHE is an effective solution that improves the microclimate conditions in the barn without the need to incur high investment and operating costs.

Proper indoor microclimate conditions are very important for production efficiency. Climate change will enforce further investments in solutions that eliminate the risk of thermal stress to farm animals' thermal stress. The analysis of the use of GAHE for the purpose of ensuring the required parameters of the microclimate of barns proves that it is advisable to undertake the research. The use of GAHE for the preparation of supply air ventilation in the ventilation processes of livestock rooms gives many possible beneficial effects. The additional costs of construction and utilization of GAHE can be compensated by an increase in revenues as the result of reduction in or elimination of summer-season heat stress associated with greater milk production.

Cooperation of the ventilation system with GAHE results in:

- Much more favorable microclimate conditions in the cowshed during the year.

- The reduction of the average air temperature and summer heat peaks in the barn during the warm season.

- The air temperature increases the possibility in winter with the same air stream as in classic solutions.

- Reduction in daily and monthly fluctuations in indoor air temperature and relative humidity, as well as a significant reduction in the occurrence of unfavorable parameters, which all translate into a higher possible milk production.

- Significant reduction in the occurrence of heat-stress conditions.

- Reduction in THI index values during summer season.

- Possibility of scaling down the amount of ventilation air in the summer season, which enables design of a system with smaller components, and the reduction in fans which drive electricity consumption.

- By passively heating the air, it allows an increase in ventilation air volume during the winter season without overcooling the animal residence zone, which also increases indoor air quality and cleanliness.

- The use of the considered solution is particularly advantageous:

- in new livestock buildings,

- $\quad$ in existing, modernized, or renovated livestock buildings.

The analysis performed shows that the use of GAHE brings benefits, especially in the case of the simplest applications. In addition, the proposed variants of controlling the operation of the ventilation system allow, apart from savings, to obtain more stable and comfortable microclimate conditions for cows. There are further benefits that can be achieved by improving the control process.

In further research work, different variants and configurations of GAHE can be considered, e.g.,

- Variable ventilation airflow controlled hourly throughout the year, customized to meet current external or internal conditions.

- $\quad$ System control based on the THI index values or other indicators.

- $\quad$ Mixing of GAHE air supply with outdoor air (Figure 2b,d).

- Active use of the GAHE bypass. 


\begin{abstract}
Author Contributions: Conceptualization, M.B., W.C. and P.K.; methodology, M.B., W.C. and P.K.; software, P.K.; validation, M.B., W.C. and P.K.; formal analysis, M.B., W.C. and P.K.; investigation, M.B., W.C. and P.K.; writing—original draft preparation, M.B., W.C. and P.K.; writing-review and editing, M.B., W.C. and P.K.; visualization, M.B., W.C. and P.K. All authors have read and agreed to the published version of the manuscript.
\end{abstract}

Funding: This research received no external funding.

Institutional Review Board Statement: Not applicable.

Informed Consent Statement: Not applicable.

Data Availability Statement: Not applicable.

Conflicts of Interest: The authors declare no conflict of interest.

\title{
References
}

1. Cepiński, W.; Besler, M. Industrial applications of the air direct-contact, gravel, ground heat exchanger. In Proceedings of the E3S Web of Conferences, Wrocław, Poland, 7 November 2017; Volume 22. [CrossRef]

2. Deutsches Institut Für Normung, e.V. DIN 18910-1-2004-11 Wärmeschutz geschlossener Stelle—Wärmedämmung und LüftungTeil 1: Planungs- und Berechnungsgrundlagen für geschlossene zwangsbelüftete Ställe.4. Available online: https://www.beuth. de/en/standard/din-18910-1/74837170 (accessed on 22 November 2021).

3. Wolski, L. Mikroklimat w Budynkach Inwentarskich; PWN: Warszawa, Poland, 1988.

4. Fiedorowicz, G.; Mazur, K. Microclimate inside the buildings of free-stall cattle barns during spring-summer season. Part I. Probl. Inz. Rol. 2011, 19, 123-134.

5. Belizgys, R.; Bagdoniene, I. Control of ammonia air pollution through the management of thermal processes in cowsheds. Sci. Total Environ. 2016, 568, 990-997. [CrossRef] [PubMed]

6. Chen, L.; Hoff, S.; Cai, L.; Koziel, J.; Zelle, B. Evaluation of Wood Chip-Based Biofilters to Reduce Odor, Hydrogen Sulfide, and Ammonia from Swine Barn Ventilation Air. J. Air Waste Manag. Assoc. 2009, 59, 520-530. [CrossRef] [PubMed]

7. Zou, B.; Shi, Z.; Du, S. Gases emissions estimation and analysis by using carbon dioxide balance method in natural-ventilated dairy cow barns. Int. J. Agric. Biol. Eng. 2020, 13, 41-47. [CrossRef]

8. Lees, A.M.; Sejian, V.; Wallage, A.L.; Steel, C.C.; Mader, T.L.; Lees, J.C.; Gaughan, J.B. The Impact of Heat Load on Cattle. Animals 2019, 9, 322. [CrossRef] [PubMed]

9. $\quad$ Sprinkle, E.; Sagers, J.K.; Hall, J.B.; Ellison, M.J.; Yelich, J.V.; Brennan, J.R.; Taylor, J.B.; Lamb, J.B. Protein Supplementation and Grazing Behavior for Cows on Differing Late-Season Rangeland Grazing Systems James. Animals 2021, 11, 3219. [CrossRef]

10. Thom, E.C. The discomfort index. Weatherwise 1959, 12, 57-60. [CrossRef]

11. National Research Council. A Guide to Environmental Research on Animals; National Academy of Science: Washington, DC, USA, 1971.

12. Yian, G.; Li, H.; Shi, Z. Evaluation of Thermal Indices as the Indicators of Heat Stress in Dairy Cows in a Temperate Climate. Animals 2021, 11, 2459. [CrossRef]

13. West, J.W. Effect of heat stress on production in dairy cattle. J. Dairy Sci. 2003, 86, 2131-2214. [CrossRef]

14. McDowell, R.E.; Hooven, N.W.; Camoens, J.K. Effects of climate on performance of Holsteins in first lactation. J. Dairy Sci. 1976, 59, 965-973. [CrossRef]

15. Negri, R.; Aguilar, I.; Feltes, G.L.; Cobuci, J.A. Selection for Test-Day Milk Yield and Thermotolerance in Brazilian Holstein Cattle. Animals 2001, 11, 128. [CrossRef]

16. Duru, S. Determination of starting level of heat stress on daily milk yield in Holstein cows in Bursa city of Turkey. Vet. Fakültesi Derg. 2018, 65, 93-198.

17. Kadzere, C.T.; Murphy, M.R.; Silanikove, N.; Maltz, E. Heat stress in lactating dairy cows: A review. Livest. Prod. Sci. 2002, 77, 59-91. [CrossRef]

18. Hansen, P.J. Exploitation of genetic and physiological determinants of embrionic resistance to elevated temperature to improve embryonic survival in dairy cattle during heat stress. Theriogenology 2007, 68, S242-S249. [CrossRef]

19. Hristov, S.; Stankowić, B.; Joksimović-Todorowić, M.; Bojkowski, J.; Davidović, V. Uticaj toplotnog stresa na proizvodnju mlečnih krava. Zb. Naučnih Rad. 2007, 13, 3-4.

20. Pinto, S.; Hoffmann, G.; Ammon, C.; Heuwieser, W.; Levit, H.; Halachmi, I.; Amon, T. Effect of two cooling frequencies on respiration rate in lactating dairy cows under hot and humid climate conditions. Ann. Anim. Sci. 2019, 19, 821-834. [CrossRef]

21. Almuhanna, E.A.; Gamea, G.R.; Osman, O.E.; Almahdi, F.M. Performance of roof-mounted misting fans to regulate heat stress in dairy cows. J. Therm. Biol. 2021, 99, 102984. [CrossRef]

22. Bang, N.N.; Gaughan, J.B.; Hayes, B.J.; Lyons, R.E.; Chanh, N.V.; Trach, N.X.; Khang, D.N.; McNeill, D.M. Characteristics of Cowsheds in Vietnamese Smallholder Dairy Farms and Their Associations with Microclimate-A Preliminary Study. Animals 2021, 11, 351. [CrossRef] [PubMed] 
23. Sarentonglaga, B.; Sugiyama, T.; Fukumori, R.; Nagao, Y. Effects of a tunnel ventilation system within the tie-stall barn environment upon the productivity of dairy cattle during the winter season. Asian-Australas. J. Anim. Sci. 2019, 32, 748-756. [CrossRef] [PubMed]

24. Doumbia, E.M.; Janke, D.; Yi, Q.; Prinz, A.; Amon, T.; Kriegel, M.; Hempel, S. A Parametric Model for Local Air Exchange Rate of Naturally Ventilated Barns. Agronomy 2021, 11, 1585. [CrossRef]

25. Doumbia, E.M.; Janke, D.; Yi, Q.; Amon, T.; Kriegel, M.; Hempel, S. CFD modelling of an animal occupied zone using an anisotropic porous medium model with velocity depended resistance parameters. Comput. Electron. Agric. 2021, 181, 105950. [CrossRef]

26. Pakari, A.; Ghani, S. Comparison of different mechanical ventilation systems for dairy cow barns: CFD simulations and field measurements. Comput. Electron. Agric. 2021, 186, 106207. [CrossRef]

27. Tomasello, N.; Valenti, F.; Cascone, G.; Porto, S.M.C. Development of a CFD Model to Simulate Natural Ventilation in a Semi-Open Free-Stall Barn for Dairy Cows. Buildings 2019, 9, 183. [CrossRef]

28. Pustovaya, O.; Pustovoy, E. Optimization of energy spending with accelerated ventilation. Web Conf. 2020, 178, 1022. [CrossRef]

29. Kowalczyk, W. Model Matematyczny Ciepła i Masy w Bezprzeponowym Gruntowym Wymienniku w Systemie Wentylacyjnym, Praca Doktorska; Wydział Inżynierii Środowiska Politechniki Wrocławskiej: Wrocław, Poland, 1988.

30. Official EnergyPlus Website, Weather Data (March 2018r). Available online: https://energyplus.net/weather-download/europe_ wmo_region_6/POL//POL_Wroclaw.124240_IMGW/all (accessed on 22 November 2021).

31. Kic, P. Effect of construction shape and materials on indoor microclimatic conditions inside the cowsheds in dairy farms. Agron. Res. 2017, 15, 426-434.

32. Kavolelis, B.; Sateikis, I. Effective cowshed insulating and ventilation system parameters. Energy Build. 2004, 36, 969-973. [CrossRef]

33. Nowak, D. Warunki Utrzymywania Bydła w Świetle Obowiązujących Przepisów; Centrum Doradztwa Rolniczego w Brwinowie Oddział w Poznaniu: Poznań, Poland, 2013; ISBN 978 83-60232-49-1. Available online: https://www.cdr.gov.pl/images/ wydawnictwa/2013/2013-WARUNKI-UTRZYMYWANIA-BYDLA-W-SWIETLE-OBOWIAZUJACYCH-PRZEPISOW.pdf (accessed on 22 November 2021).

34. Pedersen, S.; Sällvik, K. Climatization of Animal Houses Heat and Moisture Production at Animal and House Levels; Section II; International Commission of Agricultural Engineering: Chicago, IL, USA, 2002.

35. Głuski, T. Parametry Stada w Procesie Projektowania Mikroklimatu w Budynkach dla Bydła. Inżynieria Rol. $2009,13,95-101$.

36. Official Website of Ministerstwo Infrasturktury i Budownictwa, Weather Data (March 2018). Available online: http://mib.gov.pl/ 2-wskazniki_emisji_wartosci_opalowe_paliwa.htm (accessed on 22 November 2021).

37. Bagdoniene, I.; Belizgys, R. The problems of microclimate in lithuanian cowsheds. In Proceedings of the International Scientific Conference “Rural Development 2019”, Kaunas, Lithuania, 26-28 September 2019.

38. Wójcik, A.; Mituniewicz, T.; Dzik, S.; Kostrubiec, Ł.; Wolska, A.; Dzięgiel, D. Environmental indicators for assessing the welfare of dairy cattle housed indoors. Sci. Ann. Pol. Soc. Anim. Prod. 2017, 13, 71-82. [CrossRef] 